\title{
Obesity and Race Alter Gene Expression in Skin
}

Jeanne M. Walker ${ }^{1+*}$, Sandra Garcet ${ }^{2+}$, Jose O. Aleman ${ }^{3,4}$, Christopher E. Mason ${ }^{5}$, David Danko $^{5}$, Simone Zuffa ${ }^{6}$, Jonathan R. Swann ${ }^{6,7}$, James Krueger $^{2}$, Jan L. Breslow ${ }^{3}$, Peter R. Holt ${ }^{3 *}$

${ }^{1}$ The Rockefeller University Hospital, New York, N.Y. 10065, USA.

${ }^{2}$ The Rockefeller University, Laboratory of Investigational Dermatology, New York, N.Y. 10065, USA.

${ }^{3}$ The Rockefeller University, Laboratory of Biochemical Genetics \& Metabolism, New York, N.Y. 10065, USA.

${ }^{4}$ New York University Langone Health, Laboratory of Translational Obesity Research, New York, N.Y. 10016, USA.

${ }^{5}$ Weill Cornell Medical College, New York, N.Y.10065, USA.

${ }^{6}$ Department of Metabolism, Digestion, and Reproduction, Imperial College London, U.K.

${ }^{7}$ School of Human Development and Health, Faculty of Medicine, University of Southampton, UK.

*Corresponding author: walkerj@ rockefeller.edu

*Corresponding author: holtp@ rockefeller.edu

+ These authors contributed equally to this work

Keywords: Obesity; race; skin gene expression; skin microbiota; skin metabolites. 
medRxiv preprint doi: https://doi.org/10.1101/2020.06.02.20120469; this version posted June 5, 2020. The copyright holder for this preprint

(which was not certified by peer review) is the author/funder, who has granted medRxiv a license to display the preprint in perpetuity.

It is made available under a CC-BY-NC-ND 4.0 International license .

\begin{abstract}
Obesity is accompanied by dysfunction of many organs, but effects on the skin have received little attention. We studied differences in epithelial thickness by histology and gene expression by Affymetrix gene arrays and PCR in the skin of 10 obese (BMI 35-50) and 10 normal weight (BMI 18.5-26.9) postmenopausal women paired by age and race. Epidermal thickness did not differ with obesity but the expression of genes encoding proteins associated with skin blood supply and wound healing were altered. In the obese, many gene expression pathways were broadly downregulated and subdermal fat showed pronounced inflammation. There were no changes in skin microbiota or metabolites. African American subjects differed from Caucasians with a trend to increased epidermal thickening. In obese African Americans, compared to obese Caucasians, we observed altered gene expression that may explain known differences in water content and stress response. African Americans showed markedly lower expression of the gene encoding the cystic fibrosis transmembrane regulator characteristic of the disease cystic fibrosis. The results from this preliminary study may explain the functional changes found in the skin of obese subjects and African Americans.
\end{abstract}


medRxiv preprint doi: https://doi.org/10.1101/2020.06.02.20120469; this version posted June 5, 2020. The copyright holder for this preprint (which was not certified by peer review) is the author/funder, who has granted medRxiv a license to display the preprint in perpetuity. It is made available under a CC-BY-NC-ND 4.0 International license .

\section{Introduction}

Obesity, defined as a body mass index (BMI) greater than $30 \mathrm{~kg} / \mathrm{m}^{2}$ [1], has become a major epidemic in industrial and emerging countries. The prevalence of obesity has doubled since the 1980's and it is now estimated that 600 million adults worldwide are obese [2]. Obesity affects many organs of the body and it is this organ dysfunction that leads to excess mortality and morbidity [3]. Much attention has focused on the consequences of obesity in the heart, liver and pancreas and other organs in which increased inflammation and oncogenesis become apparent [4]. Less attention has been paid to the effects of obesity on the skin.

Obesity increases psoriasis [5], which can be ameliorated with weight loss, and cutaneous infections [6]. Since diabetes is common in obesity, disorders such as fibroepithelial polyps and acanthosis nigricans also occur in the skin of obese subjects [7, 8]. Moreover, physiologic changes found in obese skin include increased trans-epidermal water loss with lower capacitance, dry, rough textured skin with pronounced erythema and reduced microvascular reactivity. Altered collagen formation and increased delayed-type hypersensitivity have also been reported [9].

Adipocyte depots that exist adjacent to the epidermis have distinct morphology and physiologic characteristics and are termed dermal or subdermal adipose tissue. In addition to the principal role for dermal adipocytes in lipid storage and thermal insulation [10], they also promote skin immunity [11], wound healing, and hair follicle cycling [12]. Obesity is accompanied by inflammatory immune changes in subcutaneous and visceral adipose tissues [13], but the role of inflammatory changes within the adipose layer of the skin has received little attention. Furthermore, obesity is associated with increased circulating leptin levels which appear to independently affect dermal cell proliferation and hair growth [14]. In addition, the 
microorganisms that live on the skin surface also affect skin immunity [11] so that it is important to analyse the skin microbiome comparing obese and normal individuals.

In view of the profound clinical and physiologic changes described in the skin in obesity, it would not be surprising also to find biologically important molecular changes. The present study was designed to compare gene expression in skin of healthy obese and non-obese subjects and to evaluate the potential importance of parallel changes in the microbiome and metabolites found on the adjacent skin surface and in the adipose tissue immediately below the skin. 
medRxiv preprint doi: https://doi.org/10.1101/2020.06.02.20120469; this version posted June 5, 2020. The copyright holder for this preprint (which was not certified by peer review) is the author/funder, who has granted medRxiv a license to display the preprint in perpetuity.

\section{Materials and Methods:}

\section{Subjects:}

Participants were recruited from the surrounding community through advertisements and from the Rockefeller University subject repository. Eligible were healthy, obese (BMI 35-50 $\mathrm{kg} / \mathrm{m}^{2}$ ) and non-obese (BMI $18-27 \mathrm{~kg} / \mathrm{m}^{2}$ ) postmenopausal women between the ages of 40 and 70 years. The two groups were matched by age (+/- 5 years) and defined by self-reported race and by skin colour. Exclusions were unstable weight (> 5\% change within the past three months), HIV infection, weight loss surgery, inflammatory bowel disease, history of malignancy other than non-melanoma skin cancer in the previous 5 years, generalizable or systemic skin diseases, history of a bleeding disorder, current anticoagulant therapy or regular NSAID use, current weight control medication or hypoglycaemic therapy, individuals taking oestrogen/progesterone hormones and current tobacco smokers. Also excluded were candidates with fasting blood glucose $>125 \mathrm{mg} / \mathrm{dl}$, liver function tests (ALT, AST, alkaline phosphatase) greater than 2 times the upper limit of normal (ULN), abnormal thyroid function test, or serum creatinine $>2 x$ ULN.

Fourteen obese subjects were screened, two refused skin biopsies, one was withdrawn due to an intercurrent inflammatory illness, and one was not postmenopausal by our criteria. Ten obese subjects met our inclusion criteria and underwent skin swab collections and punch biopsy. Twenty non-obese subjects were screened. Two subjects refused to undergo punch biopsy, one was withdrawn due to an intercurrent illness, two with a BMI outside the required range, one withdrew consent, one was excluded with a history of keloid formation, one with a low platelet count, one with uncontrolled hypertension. One non-obese subject who underwent skin punch biopsy was not included in the analysis because we were unable to find an age and race-matched obese subject. These 10 obese and 10 age-matched, race-matched non-obese postmenopausal 
medRxiv preprint doi: https://doi.org/10.1101/2020.06.02.20120469; this version posted June 5, 2020. The copyright holder for this preprint (which was not certified by peer review) is the author/funder, who has granted medRxiv a license to display the preprint in perpetuity. It is made available under a CC-BY-NC-ND 4.0 International license .

women completed all aspects of the study (Figure 1). Six participants were Caucasian and four were African Americans in each group. Post-menopausal women were chosen to exclude effects of the menstrual cycle upon study end points and to exclude gender effects.

Based on preliminary data from a previous study comparing skin from seven obese and six non-obese postmenopausal women, there was a variation of $45 \%$ in a set of RT-PCR genes (unpublished data). Assuming the same variation and proportion of differentially expressed genes to be $5 \%$, we calculated that a sample size of $n=10$ subjects per group, matched by age and race, would provide $80 \%$ power at a $5 \%$ false-discovery rate to detect the expected number of differentially expressed genes based on a threshold of 2-fold changes.

\section{Design and Setting:}

This was an open-label comparison of a group of 10 postmenopausal obese women and 10 postmenopausal non-obese women who were age-matched (+/-5 years) and race-matched. Screening comprised a complete history and physical examination and fasting blood testing for complete blood count, sedimentation rate, comprehensive chemistry panel, lipid panel, thyroid function tests, hepatitis C antibody, uric acid, and haemoglobin A1C. Observing Good Clinical Practice guidelines, all participants read and signed an informed consent document approved by the Institutional Review Board and the Advisory Committee for Clinical and Translational Science at The Rockefeller University (Protocol JWA-0921).

\section{Procedure Methods:}

Anthropometric measurements: Body weight was measured daily to the nearest $0.1 \mathrm{~kg}$ using a Scale-Tronix 5002 scale (Welch Allyn, Skaneateles Falls, N.Y.) with precision of +/- 0.1kg. Subjects were weighed in a hospital gown, after an overnight fast and post-voiding. Height was measured to the nearest $0.1 \mathrm{~cm}$ at baseline with a Seca-216 stadiometer (Hamburg, Germany) in 
medRxiv preprint doi: https://doi.org/10.1101/2020.06.02.20120469; this version posted June 5, 2020. The copyright holder for this preprint (which was not certified by peer review) is the author/funder, who has granted medRxiv a license to display the preprint in perpetuity. It is made available under a CC-BY-NC-ND 4.0 International license .

$1 \mathrm{~cm}$ increments. Body mass index (BMI) was calculated as $\left(\mathrm{kg} / \mathrm{m}^{2}\right)$, using the NIH Standard Metric BMI calculator.

Blood collection and analysis: Fasting blood samples were analysed in the Clinical Pathology Laboratory of the Memorial Sloan-Kettering Cancer Center for complete blood count, electrolytes, glucose, creatinine, blood urea nitrogen, liver function, C-reactive protein, sedimentation rate, and uric acid. Research serum samples were drawn pre and post intervention, aliquoted and stored at $-80^{\circ} \mathrm{C}$ for subsequent analysis.

Skin swabbing: Subjects were permitted to shower but did not wash the planned biopsy area over the mid-lower abdomen with soap for 3 days before the biopsy.

For microbiome analysis, two areas of skin approximately 10 x $10 \mathrm{~cm}$ were swabbed using the eSwab collection and preservation system for aerobic, anaerobic, and fastidious bacteria (Copan Diagnostics, Marietta, CA). Swabs were labelled, sealed separately in the provided tubes, and immediately stored at $-80^{\circ} \mathrm{C}$. For metabolome analysis, two different areas of skin approximately $15 \times 15 \mathrm{~cm}$ were swabbed using saline-moistened sterile cotton-tipped applicators. The tips were cut, sealed in separate sterile collection tubes, and immediately stored at $-80^{\circ} \mathrm{C}$. Details of the analyses of the microbiome and metabolome skin swabs are found in the supplement under "Methods". The scientists making these measurements and statistical analyses were blinded to the group assignments.

Skin biopsy: After the skin swabbing, the abdominal site was cleansed with (3) Chloraprep swabs (chlorhexidine 2\% and isopropyl alcohol 70\%, Becton Dickinson, Canaan, CT). Using sterile technique, local anaesthesia was induced by infiltration of the area with $4 \mathrm{ml}$ of lidocaine $1 \%$ (Hospira, Inc., Lake Forest, IL) mixed with $1 \mathrm{ml}$ sodium bicarbonate. The skin biopsy was performed using a $6 \mathrm{~mm}$ punch (Miltex Instruments, York, PA). Fat tissue was carefully 
medRxiv preprint doi: https://doi.org/10.1101/2020.06.02.20120469; this version posted June 5, 2020. The copyright holder for this preprint (which was not certified by peer review) is the author/funder, who has granted medRxiv a license to display the preprint in perpetuity. It is made available under a CC-BY-NC-ND 4.0 International license .

removed from the skin core of the biopsy using a scalpel. The skin core and fat were placed separately in RNAlater Stabilization Solution (Thermo Fisher Scientific, Fair Lawn, N.J.), refrigerated for 24 hours, and then frozen at $-80^{\circ} \mathrm{C}$. The biopsy site was sutured closed and a dry sterile dressing was applied. Subjects were discharged with wound care instructions and scheduled to return for suture removal.

Gene-array and quantitative real-time PCR analysis: RNA was extracted, followed by hybridization to Affymetrix Human U133 Plus 2.0 gene arrays (Santa Clara, CA) or quantitative RT-PCR as previously described $[15,16]$.

All statistical analyses were carried out in R (Limna) Log 2-transformed qRT-PCR measurements (hARP normalized) and microarray expression values were assessed with a mixed-effect. The fixed factors were condition (obese vs non-obese), race (African American vs Caucasian), with random intercept for each subject. Quality control of microarray chips was carried out using standard QC metrics and R package microarray quality control. Images were scrutinized for spatial artefacts using Harshlight [17]. Expression measures were obtained using the GCRMA algorithm [18]. A batch effect corresponding to the hybridization date was detected by principal components analysis (PCA) and adjusted using the ComBat function from the SVA package. Probe sets with at least 3 samples with expression values $>3$ were kept for further analysis. Fold changes for the comparisons of interest were estimated, and hypothesis testing was conducted with contrasts under the general framework for linear models with the limma package. $\mathrm{P}$ values from the moderated (paired) t-tests were adjusted for multiple hypotheses using the Benjamini-Hochberg procedure. Hierarchical clustering was performed with Euclidean distance and a McQuitty agglomeration scheme $[18,19]$. 
medRxiv preprint doi: https://doi.org/10.1101/2020.06.02.20120469; this version posted June 5, 2020. The copyright holder for this preprint (which was not certified by peer review) is the author/funder, who has granted medRxiv a license to display the preprint in perpetuity. It is made available under a CC-BY-NC-ND 4.0 International license .

Data deposited into Gene Expression Omnibus (GEO) repository. GEO accession number pending. 
medRxiv preprint doi: https://doi.org/10.1101/2020.06.02.20120469; this version posted June 5, 2020. The copyright holder for this preprint (which was not certified by peer review) is the author/funder, who has granted medRxiv a license to display the preprint in perpetuity.

It is made available under a CC-BY-NC-ND 4.0 International license .

\section{Results:}

This study was performed in ten healthy obese and ten healthy non-obese postmenopausal women matched for age and race. Obese subjects had a mean weight of $109 \mathrm{~kg}$, BMI of $40.7 \mathrm{~kg} / \mathrm{m}^{2}$, and waist circumference of $117 \mathrm{~cm}$. Non-obese subjects had a mean weight of $59.4 \mathrm{~kg}$., BMI of $22.4 \mathrm{~kg} / \mathrm{m}^{2}$, and waist circumference of $80.4 \mathrm{~cm}$ (Table S1). The skin thickness for subjects with obesity was not significantly different from that of non-obese subjects (Figure 2).

\section{Gene expression analysis of the skin:}

The 50 most differentially expressed genes in the skin between obese and non-obese subjects are displayed in the heat map in Figure 3A. Comparing gene expression in obese versus non-obese skin showed greater gene expression of S100A7A, encoding a calcium binding protein involved in psoriasis, and CORIN encoding a natriuretic peptide converting enzyme, which is expressed in the dermis and is involved in specifying skin colour. However, the expression of CREB3LA, encoding a cyclic AMP response element, was lower in the skin of obese subjects.

A PCA model constructed on 400 of the most differentially expressed genes between obese and non-obese subjects showed partial separation of the 2 groups. This difference was seen in PC1 which accounted for $69 \%$ of the variation in the included genes (Figure 3B).

The complete list of skin genes whose expression significantly differed between the two groups is shown with fold changes in Table S2. Again, the gene expression of S100A7A was 3.44-fold higher in the obese skin compared to the non-obese skin. Similarly, the expression of DEFB4A (Defensin B4A), which encodes an antimicrobial peptide (part of the beta-defensive system), and SPRR2C, which encodes a proline rich protein strongly induced during 
medRxiv preprint doi: https://doi.org/10.1101/2020.06.02.20120469; this version posted June 5, 2020. The copyright holder for this preprint (which was not certified by peer review) is the author/funder, who has granted medRxiv a license to display the preprint in perpetuity. It is made available under a CC-BY-NC-ND 4.0 International license .

differentiation of human epidermal keratinocytes, was also significantly higher in the obese skin being 3.11 and 1.7fold higher, respectively. Genes with lower expression profiles in obese subjects than non-obese included AOP that encodes aquaporin (involved in water channels present in the skin), PROM1 (prominin 1; involved in cell differentiation and proliferation) and Keratin 7 and 19 (important for fibrogenesis in the epidermis). Also, of interest was the significantly higher expression (2.82-fold) of CFTR, the cystic fibrosis transmembrane conductance receptor in non-obese subjects compared to the obese group.

QTPCR analysis of 15 genes selected from the total list of significantly differentially expressed genes in skin confirmed increased expression of the S100A (3.73-fold), DEFB4A (defensin B4A) (3.29-fold), and CORIN (2.07-fold) in the skin of obese subjects (Figure 4). Significantly lower gene expression in the skin of obese subjects was found with CFTR, (3.6fold), PROM1 (5.56-fold), and GABRP (gamma aminobutyric acid receptor) (2.9-fold).

Gene expression pathway analysis showed a broad downregulation of many pathways in obesity subjects with only 4 out of 39 of the most highly differentially expressed pathways higher in the obese (Figure 5). The pathways most down-regulated included cardiac betaadrenergic signalling, which appears to function in skin, cyclin dependent Kinase 5 (CDK5), a mutation which is important in melanoma formation and functions in skin healing, and gonadotrophic releasing hormone (GNRH) signalling, which has many extra pituitary functions.

\section{Gene expression analysis in skin fat:}

We next examined differences in gene expression between the 2 groups of subjects in subdermal fat removed from immediately below the skin portion of the biopsy. A heat map of gene expression shows a markedly different pattern between the two groups (Figure 6A). The expression of many of the genes upregulated in obese subdermal fat are involved with 
medRxiv preprint doi: https://doi.org/10.1101/2020.06.02.20120469; this version posted June 5, 2020. The copyright holder for this preprint (which was not certified by peer review) is the author/funder, who has granted medRxiv a license to display the preprint in perpetuity. It is made available under a CC-BY-NC-ND 4.0 International license .

inflammation and immune function including platelet activating factor PLA2G7, ILIRN involved in IL1 activation, SPPI, a cytokine that can increase interferon gamma and IL12 activity, and several serpins, mediators involved in inflammation and immune function.

The PCA plot of genes whose expression differed significantly in subdermal fat of obese and non-obese subjects (Figure 6B) clearly shows separation between the two groups. Most of the difference was seen in PC1 which includes $55 \%$ of the genes whose expression was determined.

Table S6 shows a list of genes whose expression was relatively greater in the subdermal fat of obese subjects. The expression of SPPI that encodes osteopontin, which can act as a cytokine, augmenting the action of interferon gamma and interleukin 12 was approximately 10fold higher in the obese subjects. EGFL6 expression, which encodes an epidermal growth factor found to be enhanced in obesity and alters insulin action, was increased by 8.5-fold. MMP9, which encodes metalloproteinase 9 and ILTRN, was increased by 7-fold in obesity. Genes significantly down-regulated in obese subdermal fat included SLC27A2 (acetyl-CoA-synthase; 10-fold) and C6-complement (5-fold).

By QTPCR in subdermal fat from obese subjects, the increased expression of genes encoding proteins important in inflammation and immune function was confirmed, including genes encoding proteins that determine accumulation of immune cells in adipose tissues such as CD52, the high affinity immunoglobulin gamma FC receptor (FCGR1 $\beta$ ), CCL3, CZXCL8 (interleukin 8) and CLEC7A, a pattern recognition receptor found in monocytes and other myeloid cells (Figure 7). IL17F, a member of the IL17 family, also was specifically increased in subdermal fat from the obese as compared to non-obese individuals. 
medRxiv preprint doi: https://doi.org/10.1101/2020.06.02.20120469; this version posted June 5, 2020. The copyright holder for this preprint (which was not certified by peer review) is the author/funder, who has granted medRxiv a license to display the preprint in perpetuity. It is made available under a CC-BY-NC-ND 4.0 International license .

Expression pathway analysis (Figure 8) showed upregulation of several inflammatory immune pathways including the T-helper 2, dendritic cell maturation and inflammatory signalling pathways further indicating profound effects of obesity on inflammation in subdermal fat. Dramatically lower in the obese subdermal fat was the LXR/RXR activation pathway.

\section{Gene expression analysis by race:}

Two subgroups were observed in the gene expression profiles of the skin based on the subject's race. Using self-reported data and skin colour as criteria, the data from African Americans was analysed separately from the data from Caucasians. This analysis showed striking differences in this very small group of subjects. A heatmap of the 50 most differentially expressed genes in skin from obese subjects divided by race is shown in Figure 7. No clear difference in gene expression is seen by race in the non-obese subjects. In contrast, gene expression clearly differed between obese African Americans and obese Caucasians (Figure 9A). The marked difference between obese African American and Caucasian subjects in gene expression is illustrated in the PCA plot in Figure 9B being responsible for the largest source of variation $(\mathrm{PC} 1)$.

A list of genes whose expression significantly differed between the obese African Americans and the obese Caucasians is shown in Tables S6 \& S7. The expression of SLC6A4, a serotonin transporter, CORIN, and COL8AI - a collagen gene encoding a protein that is dysregulated in atopic eczema, was higher in African Americans, while the expression of SCCB2A2, the secretoglobin expressed in skin sweat glands, and CFTR was expressed higher in Caucasians.

Comparing the skin of obese African Americans to obese Caucasians by QTPCR, the former showed significantly lower expression of MYBCPI (5.16-fold) and PROM1 (4.3-fold) 
medRxiv preprint doi: https://doi.org/10.1101/2020.06.02.20120469; this version posted June 5, 2020. The copyright holder for this preprint (which was not certified by peer review) is the author/funder, who has granted medRxiv a license to display the preprint in perpetuity.

It is made available under a CC-BY-NC-ND 4.0 International license .

and CFTR (Figure 10). In contrast, there was a small increase in the expression of CORIN (2.2fold), a gene encoding the atrial naturalistic peptide converting enzyme and BMP2 (1.33- fold) also present in the skin compared to obese Caucasians.

Pathway analysis (Figure 11) found no race-related differences in the non-obese samples. However, in the obese, there was markedly reduced expression of oestrogen mediated s-phase entry pathway, aryl hydrolase receptor signalling, pathway, and cell cycle regulation through cyclins pathways in the African Americans compared to the skin of the Caucasian group.

\section{Microbiota analysis:}

We next examined whether the microbiota collected from skin swabs around the biopsy site differed between the obese and non-obese subjects. We generated taxonomic profiles for each sample using KrakenUniq and a database built from all available microbial species in RefSeq. We measured the total number of AMR genes detected in each sample by aligning reads to MegaRES.

Overall differences between groups were minor. No significant differences were noted in average taxonomic alpha diversity as measured by either Shannon's entropy or richness between the groups. A PCA plot of the taxonomic profiles showed slight separation between obese and lean samples and slightly higher beta diversity for obese samples however these differences were minor (Figure 15A).

\section{Differentially Abundant Taxa}

At the given sample size $(n=10)$ no taxa were identified as significantly differentially abundant after Benjamini-Hochberg correction. Before correction five taxa were significantly 
medRxiv preprint doi: https://doi.org/10.1101/2020.06.02.20120469; this version posted June 5, 2020. The copyright holder for this preprint

(which was not certified by peer review) is the author/funder, who has granted medRxiv a license to display the preprint in perpetuity.

It is made available under a CC-BY-NC-ND 4.0 International license.

differentially abundant at $p=0.005$ (Wilcox test). These five taxa were Corynebacterium

aurimucosum, Corynebacterium jeikeium, Corynebacterium urealyticum, Streptococcus

salivarius, and Streptococcus sp. A12. All five taxa were more abundant in samples from obese

subjects on average.

Metabolome analysis: As highlighted by the PCA analysis, no variation in the metabolites analysed by liquid chromatography-mass spectrometry from the skin swabs was observed between the obese and non-obese individuals (PCA supplemental Figure S1). Similarly, no racerelated metabolic variation was observed. These results were further confirmed by the poor predictive ability of the orthogonal projection to latent structures-discriminant analysis (OPLSDA) models comparing the two different racial groups. 
medRxiv preprint doi: https://doi.org/10.1101/2020.06.02.20120469; this version posted June 5, 2020. The copyright holder for this preprint (which was not certified by peer review) is the author/funder, who has granted medRxiv a license to display the preprint in perpetuity.

It is made available under a CC-BY-NC-ND 4.0 International license .

\section{DISCUSSION}

Few comprehensive reviews of skin changes occurring with obesity have been conducted despite over $40 \%$ of the US population being obese [20]. A broad review of the physiologic and clinical consequences and associations was published by Hirt et al in 2019 [21]. The authors include a discussion of circulatory and lymphatic changes which may enhance the frequency and severity of skin ulceration and provide a comprehensive review of skin disorders that can be associated with obesity, expanding on previous reviews [22] and studies in rodents [23].

In our study, the thickness of the epidermis did not differ between the obese and nonobese subjects. Our data contrasts with a Japanese study in which skin taken from women undergoing breast reconstruction showed a shift to greater epidermal thickness in the obese when compared to non-obese subjects, but the variation was very large [24]. In another study in obese subjects in which dermal structure in abdominal skin was visualized as echogenicity using ultrasound scanners, weight reduction decreased dermal thickness in about half of the subjects [25]. A previous study also observed no increase in skin thickness in obese subjects weighing up to $200 \mathrm{~kg}$. [26]. In rats with obesity and diabetes mellitus, epidermal thickness was reported as lower than in normal weight animals [27]. Six months of caloric restriction in mice increased epidermal thickness almost twofold [28].

An important cutaneous manifestation of obesity is chronic skin ulceration which can result from pressure from the weight of the body on the perineum or back and from venous congestion and a reduced blood supply to the lower extremity [22]. Our data suggest potential molecular factors that could contribute to defects in wound healing including altered blood flow, and less mediators of the normal healing process. 
medRxiv preprint doi: https://doi.org/10.1101/2020.06.02.20120469; this version posted June 5, 2020. The copyright holder for this preprint (which was not certified by peer review) is the author/funder, who has granted medRxiv a license to display the preprint in perpetuity. It is made available under a CC-BY-NC-ND 4.0 International license .

Normal delivery of oxygen and nutrients are crucial for wound healing and a reduced blood flow could exacerbate skin ulceration. Impaired vasodilatation and vasoconstriction occur early during the development of obesity [29]. Although total blood flow is increased in obesity [30] and skin temperature can be higher [31] the microvasculature may be inadequate to maintain the viability of healing skin tissues. The skin microcirculation is maintained by appropriate responses to need in part by endothelin-1 activity which can alter blood flow [32]. Additionally, reduced skin blood flow in obesity could be exacerbated by inflammatory changes in adjacent adipose tissue [29]. Our studies showed reduced endothelin-1 gene expression in the skin of obese subjects and pronounced inflammation in the subdermal fat. Proinflammatory cytokines from such inflamed fat also stimulates S100A7 and DEfB4A expression and can cause endothelial dysfunction in local blood vessels in part due to inadequate endothelin-1 action [33].

The S100A7 gene showed the greatest differential upregulation in the skin of obese compared to non-obese subjects. This gene encodes a protein which functions in cell cycle proliferation and differentiation and strengthens the skin-tight-junction barrier. The proinflammatory cytokines IL 17 and IL22, which are secreted from obese adipose tissue, stimulate S100A7 expression in keratinocytes. [34].

In contrast, the beta-adrenergic receptor pathway was the most downregulated in the skin of obese subjects in our study. Keratinocytes express only beta-2 adrenergic receptors for the catecholamines epinephrine and norepinephrine [35]. Skin wounding generates epinephrine which binds to its receptors resulting in excessive adrenergic activity and reduced skin wound healing by altering keratinocyte migration [36]. Defects in beta adrenergic activation are associated with the severity of atopic dermatitis and psoriasis [37]. Whether these changes affect 
medRxiv preprint doi: https://doi.org/10.1101/2020.06.02.20120469; this version posted June 5, 2020. The copyright holder for this preprint (which was not certified by peer review) is the author/funder, who has granted medRxiv a license to display the preprint in perpetuity. It is made available under a CC-BY-NC-ND 4.0 International license .

keratinocyte functions enough to contribute to defective healing of skin wounds in obese skin has not been established.

Increased inflammatory-immune activity has been extensively described in obese subcutaneous and visceral fat [38]. However, several observations suggest that subdermal fat differs in molecular composition and in function from adipose tissue in other sites [39]. Increased inflammation in dermal fat also may result in altered skin microvascular reactivity as shown in mice [23] and in skin temperature in humans [31]. Clinically, obesity may precede psoriasis at least in children [40]. The skin barrier is maintained by normal keratinocyte proliferation but the expression of several genes encoding proteins determining optimal proliferation were altered in the skin of obese subjects. As an example, the gonadotrophin releasing hormone $(\mathrm{GNRH})$ pathway was significantly reduced in the skin of the obese compared to non-obese subjects [41]. Although GNRH is a central regulator of reproductive functions, it also may help regulate cell proliferation and cell motility [42].

Subdermal fat (dWAT) of obese subjects showed a generalized increase in inflammatoryimmune activity compared to the non-obese including changes in genes encoding proteins that induce leucocyte attraction, increased activity of the TH1 pathway and in dendritic cell activation. Furthermore, there was evidence of a major increase in signalling by TREM a receptor for MCP and TNF $[43,44]$ and in osteopontin encoding a protein that increases interferon gamma and IL-12 activity.

There is extensive literature showing that obesity is accompanied by intense inflammatory-immune changes in subcutaneous and visceral fat [38] but subdermal fat has received little attention. Adipocytes stimulate follicle regeneration [45], are recruited to skin wounds [46], have been described as a $1 \mathrm{~mm}$ thick layer [47] or as pilosebaceous units (dWAT) 
medRxiv preprint doi: https://doi.org/10.1101/2020.06.02.20120469; this version posted June 5, 2020. The copyright holder for this preprint (which was not certified by peer review) is the author/funder, who has granted medRxiv a license to display the preprint in perpetuity. It is made available under a CC-BY-NC-ND 4.0 International license .

with a high turnover rate, an important factor in skin scarring [48]. Adipocytes secrete antimicrobial peptides and cytokines that signal hair follicles [44] to activate and modulate rates of hair growth and facilitate wound healing from injury and infection [50]. These data demonstrate the unique plasticity of these adipocytes in maintenance of skin homeostasis [51].

There were significant differences between the skin of obese African Americans compared to obese Caucasians. Remarkably, this was evident even though only 4 paired obese and 4 non-obese African Americans and 6 paired obese and non-obese Caucasian subjects were studied. Differences occurred in epidermal thickness, oestrogen metabolism, aquaporin and hydrocarbon receptor signalling and in gene expression encoding cadherins, platelet activating factors and solute carriers, including CFTR.

We found a trend $(\mathrm{p}=0.08)$ for a wider epidermis in the African American subjects than in Caucasians. Some [51, 52] but not all [53] previous studies have also shown that African Americans have increased skin thickness as well as a wider cornified layer, greater desquamation [54] and differences in skin lipids but a lower water content [55]. African Americans skin is said to age at a slower rate with less wrinkling and sagging, better barrier function but greater sensitivities to exogenous chemicals [56] and poorer wound healing rate [57].

In our study, skin gene expression in non-obese African Americans and Caucasians showed very few differences but the obese groups differed widely. In African Americans, the expression of the SLCA4 gene encoding a serotonin transporter (SERT), which can enhance skin sensitivity, was increased as was 5-hydroxytryptophane which stimulates keratinocyte

Oestrogens have many beneficial effects on skin physiology since the skin of postmenopausal women suffers defects which leads to "aging skin" changes and oestrogens prevent or reverse many of these effects [58]. Thus, the increase in oestrogen pathway gene expression 
medRxiv preprint doi: https://doi.org/10.1101/2020.06.02.20120469; this version posted June 5, 2020. The copyright holder for this preprint (which was not certified by peer review) is the author/funder, who has granted medRxiv a license to display the preprint in perpetuity. It is made available under a CC-BY-NC-ND 4.0 International license .

may be important to explain why the skin of African American ages more slowly than that of Caucasians. Oestrogens can stimulate greater fibroblast proliferation with thickening of the skin [59] and can act as an antioxidant [60].

The expression of the aryl hydrocarbon receptor (AHR) signalling pathway was lower in African Americans than Caucasians. The action of AHR on keratinocytes is part of the ultraviolet light stress response [61]. In the absence of the AHR, UVB exposure induces less production of melanocytes. Possibly, skin tanning and pigmentation may involve AHR signalling [62] and that black skin requires less AHR activity. However, reduced AHR activity may, at the same time, enhance inflammatory skin conditions such as psoriasis [63].

Our study in African Americans showed an about 4-fold lower expression of the CFTR gene that encodes the cystic fibrosis transmembrane conductor regulator, a channel protein that regulates chloride transport across membranes. Abnormalities of this gene, which has over 2000 mutations, is the cause of human cystic fibrosis. The incidence of cystic fibrosis is lower in African Americans (1 in 15,000) compared to about 1 in 2500 in Caucasians. One reason for a lower incidence may be that mutation testing that is routinely performed at birth in developing countries is based on the mutations seen in patients in the United States [64] and that the mutation spectrum in African nations differs significantly from that seen in Caucasians in the United States and in Europe [65]. The CFTR protein also functions in normal skin since defects in skin wound healing occur when CFTR protein function is genetically deranged [66]. CFTR expression is found in multiple layers of the skin [67] even though the skin is not an epithelial transport system. In vivo and in vitro studies have shown CFTR upregulation in early and late wound healing in CFTR -1-knock out mice [68]. Whether reducing CFTR function contributes to delayed wound healing in obesity remains to be determined. 
medRxiv preprint doi: https://doi.org/10.1101/2020.06.02.20120469; this version posted June 5, 2020. The copyright holder for this preprint (which was not certified by peer review) is the author/funder, who has granted medRxiv a license to display the preprint in perpetuity. It is made available under a CC-BY-NC-ND 4.0 International license .

Regulation of body temperature is by sweating; water is excreted via sweat glands, evaporates, and sodium is reabsorbed by epithelial sodium channels $(\mathrm{ENaC})$. The main physiologic regulator for this process is the renin aldosterone system whereby aldosterone binds to mineralocorticoid receptors which are expressed in keratinocytes. In cystic fibrosis, absorption of salt is impeded despite a functional $\mathrm{ENaC}$, so that sweat sodium is poorly reabsorbed. ENaC and CFTR appear to localize in "channels" in sweat glands.

In obesity and African Americans there is evidence of differences in skin moisture with increase in trans epidermal water loss(70) and capacitance resulting in dryer, rougher and more scaly skin [22]. Factors in our study that may be responsible include lower expression of aquaporin which is 5.8-fold greater in Caucasians and changes in ion transport. Aquaporins represent membrane proteins that function to form water channels and are involved in water homeostasis and skin hydration [69]. Although the impact of this relative increase in aquaporin-5 gene expression in Caucasians may have on the biology of the skin is presently unclear, skin hydration and wound healing [70] do differ between the skin of Caucasian subjects and African Americans.

The most detailed previous evaluation of differences between the skin biology in African Americans and Caucasians were performed with in vitro reconstructed skin [54] using isolated primary cells, keratinocytes and dermal fibroblasts from the same donor in long- term culture $[71,72]$. The authors examined skin types II, II, IV from four African American and Caucasian donors to evaluate structure using immunohistochemistry, microarrays for gene expression and proteomics. They described increased convolutions in African American skin like that seen in our studies in vivo, but also no difference in skin thickness. In addition, they reported about 425 genes that were differentially expressed that function predominantly in lipid and filaggrin 
medRxiv preprint doi: https://doi.org/10.1101/2020.06.02.20120469; this version posted June 5, 2020. The copyright holder for this preprint (which was not certified by peer review) is the author/funder, who has granted medRxiv a license to display the preprint in perpetuity. It is made available under a CC-BY-NC-ND 4.0 International license .

processing. Similar to our findings, they described significant differences in the expression of SLC44A5, but also genes and proteins involved in terminal differentiation and concluded that the dermal-epidermal junction length was 3-fold greater in African Americans than in Caucasians providing an expanded exchange area between these layers of the skin.

We examined skin microbiota derived from swabbing the surface of the skin adjacent to the site of the skin biopsy but found only minor differences between obese and non-obese subjects in the structure of these microbiota. A PCA plot suggested that microbiota from nonobese subjects were more tightly clustered than from the obese but there was much overlap. Skin surface microbiota interact closely with adjacent skin [73], are fundamental to skin physiology and immunity and are important as secondary factors that can determine the course and treatment of primary skin disorders [74]. Skin infections such as folliculitis and erysipelas are more common in obesity. We have found only one study in the literature that attempted to determine effects of obesity on the skin microbiome of "healthy" individuals. That study used data derived from the American Gut Project which gathered oral, faecal, and skin samples from the public at large [75]. Skin samples from 81 self-reported obese, 80 underweight and 580 normal weight individuals from around the world suggested that obesity was accompanied by an increase in Corynebacterium species [76]. Vongsa [77] and Rood [78] reported that obesity led to no significant changes in the distribution of skin microbiota in premenopausal or pregnant women. Since we only examined a small number of subjects it was not possible to draw conclusions on effects of obesity upon skin microbiota. However, the data we have made it unlikely that microbiota played a crucial role in the molecular changes within the skin that we observed between the obese and non-obese or between African Americans and Caucasian subjects. 
medRxiv preprint doi: https://doi.org/10.1101/2020.06.02.20120469; this version posted June 5, 2020. The copyright holder for this preprint (which was not certified by peer review) is the author/funder, who has granted medRxiv a license to display the preprint in perpetuity. It is made available under a CC-BY-NC-ND 4.0 International license .

No significant differences were found in the metabolic profiles of the skin swabs collected close to the site of the biopsy in any of our groups. Julia Oh [79] compared metabolites derived from differing skin sites and emphasized the marked variation between individuals. Others explored the potential importance of measuring sweat metabolites in studies of the skin [80]. None of these studies focused specifically on obesity or the ethnicity of the subjects.

In summary, we acknowledge that the number of subjects in our study was very small, but the data was reproducible by differing techniques. We show that the non-exposed abdominal skin of obese post-menopausal female subjects differs from that of age and race matched nonobese post-menopausal women. Although epidermal thickness of the 2 groups did not differ, there was marked upregulation of the S100A7 gene that encodes proteins that can alter skin oxygenation and can contribute to poor wound healing of skin ulcers that can afflict obese skin. Subdermal fat showed marked upregulation of genes encoding inflammatory and immune altering proteins like what has been described in deep subcutaneous and visceral adipose tissues in obesity.

We show evidence that points to differences between the skin of African American and Caucasian subjects. The molecular changes observed suggested impairment of the water and solute transport as well as aryl hydrocarbon receptor action in the skin of African Americans. Neither skin surface microbiota nor metabolites were altered to suggest their involvement in the skin changes that we observed, but the subdermal adipose tissue inflammatory-immune activity is likely to have been important. 
medRxiv preprint doi: https://doi.org/10.1101/2020.06.02.20120469; this version posted June 5, 2020. The copyright holder for this preprint

(which was not certified by peer review) is the author/funder, who has granted medRxiv a license to display the preprint in perpetuity.

It is made available under a CC-BY-NC-ND 4.0 International license.

\section{Acknowledgements}

We thank the participants and clinical research staff who made this clinical study possible.

We thank Pat Gilleaudeau, FNP for assistance with the punch biopsy procedure

We thank Inna Cueto for staining and photographing the specimen slides

We thank Chandrima Bhattacharya for assistance with microbiome analysis

This research was supported in part by RUCCTS grant \# UL1TR001866 from the National

Center for Advancing Translational Sciences (NCATS), National Institutes of Health (NIH)

Clinical and Translational Science Award (CTSA) Program (JMW).

JOA was funded by the Center for Diseases of the Digestive System and Sackler Center for

Bionutrition at Rockefeller University, AHA 17-SFRN33520045 and K08-DK117064 (NIH) at

NYU Langone Health. 


\section{Author Contributions}

JMW designed and conducted the study

SG evaluated the data and did the statistical analysis

JOA helped to evaluate and write the manuscript

CM helped to analyse and write up the microbiota data

DD helped to analyse and write up the microbiota data

SZ helped run and analyse the metabolite data

JS helped design, analyse, and write up the metabolite data

JK helped to analyse and write up the data

JLB helped to analyse, interpret and write up the data

PRH designed, analysed, interpreted, and wrote up the data

Author approval: All authors have read the manuscript and approved its contents.

Disclosures: All authors have completed the ICMJE uniform disclosure form at Www.icmje.org/coi_disclosure.pdf and declare: no support from any organisation for the submitted work.

JMW received research grants from RUCCTS grant \# UL1TR001866 from the National Center

for Advancing Translational Sciences (NCATS), National Institutes of Health (NIH) Clinical and Translational Science Award (CTSA) Program.

JOA received research grants from the Center for Diseases of the Digestive System and Sackler Center for Bionutrition at Rockefeller University, AHA 17-SFRN33520045 and K08-DK117064 (NIH) at NYU Langone Health 
medRxiv preprint doi: https://doi.org/10.1101/2020.06.02.20120469; this version posted June 5, 2020. The copyright holder for this preprint (which was not certified by peer review) is the author/funder, who has granted medRxiv a license to display the preprint in perpetuity.

It is made available under a CC-BY-NC-ND 4.0 International license .

Data Availability Statement: All data referred to in the manuscript is freely available and can be found in the body of the manuscript or in the supplemental material. Gene expression data was deposited into Gene Expression Omnibus (GEO). The GEO number is pending. 
medRxiv preprint doi: https://doi.org/10.1101/2020.06.02.20120469; this version posted June 5, 2020. The copyright holder for this preprint (which was not certified by peer review) is the author/funder, who has granted medRxiv a license to display the preprint in perpetuity. It is made available under a CC-BY-NC-ND 4.0 International license .

\section{References}

1. Apovian, C. Obesity: definition, co-morbidities, causes, and burden. Am J Manag Care. 22, S176-S185. (2016).

2. Ashkan, A. et al. The Global Burden of Disease (GBD) 2015 Obesity Collaborators: health effects of overweight and obesity in 195 countries over 25 years. $N$ Eng J Med. 377, 13-27. (2017).

3. Gadde, K.M., Martin, C.K., Berthoud, H. \& Heymsfield, S.B. Obesity: pathophysiology and management. J Am Coll of Cardiol. 71, 69-84. (2018).

4. Kloting, N. \& Bluher, M. Adipocyte dysfunction, inflammation, and metabolic syndrome. Rev Endocr Disord. 15, 277-287. (2014).

5. Garcia Hidalgo L. Dermatological complications of obesity. Am J Clin Dermatol. 3, 497506. (2002).

6. Hossler E.W., Maroon, M.S. \& Mowad, C.M. Gastric bypass surgery improves psoriasis. J Am Acad Dermatol. 65, 198-200. (2011).

7. Lonnberg, A.S. et al. Association of psoriasis with the risk for type 2 diabetes mellitus and obesity. JAMA Dermatol. 152, 761-767. (2016).

8. Shipman, A.R. \& Millington, G.W.M. Obesity and the skin. Br J Dermatol. 165, 743750. (2011).

9. Francischetti, E.A. et al. Skin capillary density and microvascular reactivity in obese subjects with and without metabolic syndrome. Microvasc Res. 81, 325-330. (2011).

10. Mori, S. et al. Characterization of skin function associated with obesity and specific correlation to local/systemic parameters in American women. Lipids Health Dis. 16, 113. (2017). 
medRxiv preprint doi: https://doi.org/10.1101/2020.06.02.20120469; this version posted June 5, 2020. The copyright holder for this preprint (which was not certified by peer review) is the author/funder, who has granted medRxiv a license to display the preprint in perpetuity. It is made available under a CC-BY-NC-ND 4.0 International license .

11. Belkaid, Y. \& Segre, J.A. Dialogue between skin microbiota and immunity. Science. 346, 954-959. (2016).

12. Festa, E. et al. Adipocyte lineage cells contribute to the skin stem cell niche to drive hair cycling. Cell. 146, 761-771. (2011).

13. Crewe, C., An, Y.U. \& Scherer, P.E. The ominous triad of adipose tissue dysfunction: inflammation, fibrosis, and impaired angiogenesis. J Clin Invest.127, 74-82. (2017).

14. Poeggeler, B. et al. Leptin and the skin: a new frontier. Exp Dermatol. 19, 12-18. (2009).

15. Brunner, P.M. et al. A mild topical steroid leads to progressive anti-inflammatory effects in the skin of patients with moderate-to-severe atopic dermatitis. J Allergy Clin Immunol. 138, 169-178. (2016).

16. Tintle, S. et al. Reversal of atopic dermatitis with narrow-band UVB phototherapy and biomarkers for therapeutic response. J Allergy Clin Immunol. 128, 583-593. (2011).

17. Suarez-Farinas, M, Pelligrino, M., Wittowski, K.M. \& Magnasco, M.O. Harshlight: a “corrective make-up” program for microarray chips. BMC Bioinform. 6, 294. https://doi.org/10.1186/1471-2105-6-294. (2005).

18. Wu, Z., Irazzary, R., Gentleman, R., Martinez-Murillo, F. \& Spencer, F. A model-based background adjustment for oligonucleotide expression arrays. J Am Stat Assoc. 99, 909917. (2004).

19. Suarez-Farinas, M. et al. Nonlesional atopic dermatitis skin is characterized by broad terminal differentiation defects and variable immune abnormalities. J Allergy Clin Immunol. 127, 954-964. (2011). 
medRxiv preprint doi: https://doi.org/10.1101/2020.06.02.20120469; this version posted June 5, 2020. The copyright holder for this preprint

(which was not certified by peer review) is the author/funder, who has granted medRxiv a license to display the preprint in perpetuity.

It is made available under a CC-BY-NC-ND 4.0 International license .

20. Hales, C.M. et al. Prevalence of obesity among adults and youth: United States 20152016. NCHS Data Brief no.288, Hyattsville, MD: National Center for Health Statistics. (2017).

21. Hirt, P.A., Castillo, D.E., Yosipovitch, G. \& Keri, J.E. Skin changes in the obese patient. J Am Acad Dermatol. 81, 1037-1057. (2019).

22. Yosipovitch, G., DeVore, A. \& Dawn, A. Obesity of the skin: Skin pathophysiology and skin manifestations of obesity. J Am Acad Dermatol. 56, 901-916. (2007).

23. Aoki, M. \& Murase, T. Obesity associated insulin resistance adversely affects skin function. PLoS One. 14, eo223538 p.1-17. Doi: 10.1371/journal.pone.0223528. (2019).

24. Horie, Y. et al. Reduced skin lipid content in obese Japanese women mediated by decreased expression of rate-limiting lipogenic enzymes. PLoS One. 13, e0193830 p.113. Doi.org/10.1371/journal.pone.0193830. (2018).

25. Matsumoto, M. et al. Changes in dermal structure and skin oxidative stress in overweight and obese Japanese males after weight loss: a longitudinal observation study. Skin Res Technol. 24, 407-416. (2018).

26. Black, M., Bottoms, E. \& Shuster, S. Skin collagen and thickness in simple obesity. Br Med J. 4, 149-150. (1971).

27. Boric, M. et al. Reduced epidermal thickness, nerve degeneration and increased painrelated behavior in rats with diabetes type 1 and 2. J Chem Neuroanat. 53, 33-40. (2013).

28. Forni, M.F. et al. Caloric restriction promotes structural and metabolic changes in the skin. Cell Rep. 20, 2678-2692. (2017). 
medRxiv preprint doi: https://doi.org/10.1101/2020.06.02.20120469; this version posted June 5, 2020. The copyright holder for this preprint

(which was not certified by peer review) is the author/funder, who has granted medRxiv a license to display the preprint in perpetuity.

It is made available under a CC-BY-NC-ND 4.0 International license .

29. Nguyen-Tu, M-S. et al. Inflammation-linked adaptations in dermal microvascular reactivity accompany the development of obesity and type 2 diabetes. Int J Obes. $\mathbf{4 3 ,}$ 556-566. (2019).

30. Alpert, M. A. Obesity cardiomyopathy: pathophysiology and evolution of the clinical syndrome. Am J Med Sci. 321, 225-236. (2001).

31. Katic, K., Li, R., Kingma, B. \& Zeiler, W. Modeling hand skin temperature in relation to body composition. J Therm Biol. 69, 39-48. (2017).

32. Bull, H.A. et al. Endothelin-1 in human skin: immunolocalization, receptor binding, mRNA expression and effects on cutaneous microvascular endothelial cells. $J$ Invest Dermatol. 97, 618-623. (1991).

33. Bakkar, W. Eringa, E. C., Sipkema, P. \& Vattinsberg, V. W. M. Endothelial dysfunction and diabetes: roles of hyperglycemia, impaired insulin signaling and obesity. Cell Tissue Res. 335, 165-189. (2009).

34. Mather, K. J., Mirjamohammadi, B., Lteif, A., Steinberg, H. O. \& Baron, A. D. Endothelin contributes to basal vascular tone and endothelial dysfunction in human obesity and type 2 diabetes. Diabetes. 51, 3517-3523. (2002).

35. Ruse, M. Broome, M. A., Eckert, R. L. S100A7 (psoriasin) interacts with epidermal fatty acid binding protein and localizes in focal adhesion-like structures in cultured keratinocytes. J Invest Dermatol. 121, 132-141. (2003).

36. Sivamani, R. K., Lam, S. T. \& Isserhoff, R. R. Beta adrenergic receptors in keratinocytes. Dermatol Clin. 25, 643-653. (2007). 
medRxiv preprint doi: https://doi.org/10.1101/2020.06.02.20120469; this version posted June 5, 2020. The copyright holder for this preprint (which was not certified by peer review) is the author/funder, who has granted medRxiv a license to display the preprint in perpetuity. It is made available under a CC-BY-NC-ND 4.0 International license .

37. Dasu, M. R. et al. Crosstalk between adrenergic and toll-like receptors in human mesenchymal skin cells and keratinocytes: a recipe for impaired wound healing. Stem Cells Transl Med. 3, 745-759. (2014).

38. Tyurin-Kuzmin, P. A. et al. Activation of $\beta$ adrenergic receptors is required for elevated $\alpha 1 \mathrm{~A}$-adrenoreceptors expression and signaling in mesenchymal stromal cells. Sci Rep. 6, 32835. https//doi:10.1038/rsep32835. (2016).

39. Hotamisligi, G. S. Inflammation and metabolic disorders. Nature. 444, 860-867. (2006).

40. Becker, L. et al. Excess adiposity preceding pediatric psoriasis. JAMA Dermatol. 150, 573-574. (2014).

41. Maggi, R. et al. GnRH and GnRH receptors in the pathophysiology of the human female reproductive system. Hum Reprod Update. 22, 358-381. (2016).

42. Aguilar-Rojas, A. \& Huerta-Reyes, M. Human gonadotropin-releasing hormone receptoractivated cellular functions and signaling pathways in extra-pituitary tissues and cancer cells (Review). Oncol Rep. 22, 981-990. (2009).

43. Arts, R.J.W., Joosten, L. A. B., van der Meer, J. W. \& Netea, M. G. TREM-1: intracellular signaling pathways and interaction with pattern recognition receptors. $J$ Leukoc Biol. 93, 209-215. (2013).

44. Jaitin, D. A. et al. Lipid-associated macrophages control metabolic homeostasis in Trem2-dependent manner. Cell. 178, 686-698. (2019).

45. Festa, E. et al. Adipocyte lineage cells contribute to the skin stem cell niche to drive hair cycling. Cell. 146, 761-771. (2011).

46. Schmidt, B. A. \& Horsley, V. Intradermal adipocytes mediate fibroblast recruitment during skin wound healing. Development. 140, 1517-1527. (2013). 
medRxiv preprint doi: https://doi.org/10.1101/2020.06.02.20120469; this version posted June 5, 2020. The copyright holder for this preprint (which was not certified by peer review) is the author/funder, who has granted medRxiv a license to display the preprint in perpetuity. It is made available under a CC-BY-NC-ND 4.0 International license .

47. Driskell, R. R., Jahoda, C.A., Chuong, C. M., Watt, F. \& Horsley, V. Defining dermal adipose tissue. Exp Dermatol. 23, 629-631. (2014).

48. Kruglikov, I. L. \& Scherer, P. E. Dermal adipocytes and hair cycling: is spatial heterogeneity a characteristic feature of the dermal adipose tissue depot? Exp Dermatol. 25, 258-262. (2016).

49. Guerrero-Juarez, C. F. \& Plikus, M. V. Emerging non-metabolic functions of skin fat. Nat Rev Endocrinol. 14, 163-173. (2018).

50. Plikus, M. V. et al. Regeneration of fat cells from myoblasts during wound healing. Science. 355, 748-752. (2017).

51. Weigand, D. A., Haygood, C. \& Gaylor, J. R. Cell layer and density of Negro and Caucasian stratum corneum. J Invest Dermatol. 62, 563-568. (1974).

52. Montagna, W. \& Carlisle, K. The architecture of black and white facial skin. J Am Acad Dermatol. 24, 929-937. (1991).

53. Reed, J. T., Ghadially, R. \& Elias, P. M. Skin type but neither race nor gender, influence epidermal permeability barrier function. Arch Dermatol. 131, 1134-1138. (1995).

54. Girardeau-Hubert, S. et al. Reconstructed skin models revealed unexpected differences in epidermal African and Caucasian skin. Sci Rep. 9: 7456. (2019). Retrieved from:

\section{https://www.nature.com/articles/s41598-019-43128-3}

55. Sugino, K., Imokawa, G. \& Maibach, H. I. Ethnic difference of stratum corneum lipid in relation to stratum corneum function. J Invest Dermatol. 10, 587. (1993).

56. Rawlins, A. V. Ethnic skin types: are there differences in skin structure and function? Int J Cosmet Sci. 28, 79-93. (2006). 
medRxiv preprint doi: https://doi.org/10.1101/2020.06.02.20120469; this version posted June 5, 2020. The copyright holder for this preprint (which was not certified by peer review) is the author/funder, who has granted medRxiv a license to display the preprint in perpetuity. It is made available under a CC-BY-NC-ND 4.0 International license .

57. Dua, A. \& Heller, J. A. Advanced chronic venous insufficiency: does race matter? Vasc Endovascular Surg. 51, 12-16. (2017).

59. Hibuse, T., Maeda, N., Nagasawa, A. \& Funahashi, T. Aquaporins and glycerol metabolism. Biochim Biophys Acta. 1758, 1004-1011. (2006).

58. Svoboda, R. M., DelRosso, J. Q., Zeichner, J. A. \& Draelos, Z. D. Revisiting the beneficial effects of estrogen on the skin: a comprehensive review of the literature and a look to the future. Skin. 2, 308-316. (2018).

59. Hall, G. S. \& Phillips, T. J. Estrogen and skin: the effects of estrogen, menopause, and hormone replacement therapy of the skin. J Am Acad Dermatol. 53, 555-568. (2005).

60. Gancevicieni, R. Liakou, AS. I., Theodorides, A., Makrantonaki, E. \& Zouboulis, C. C. Skin anti-aging strategies. Dermatoendocrinol. 43, 308-319. (2012).

61. Esser, C., Bargen, I., Weighardt, H., Haarmann-Stemmann, T. \& Krutmann, J. Functions of the aryl hydrocarbon receptor in the skin. Semin Immunopathol. 35, 677-691. (2013).

62. Jux, B. et al. The arylhydocarbon receptor mediates UVB radiation-induced skin tanning. J Invest Dermatol. 131, 202-210. (2011).

63. DiMeglio, P. et al. Activation of aryl hydrocarbon receptor dampers the severity of inflammatory skin conditions. Immunity. 40, 989-1001. (2014).

64. Schrijver, I., et al. The spectrum of CFTR variants in nonwhite cystic fibrosis patients: implications for molecular diagnostic testing. J Mol Diagn.18, 39-50. (2016).

65. Stewart, C. \& Pepper, M. S. Cystic fibrosis in the African diaspora. Ann Am Thorac Soc. 14, 1-7. (2017).

66. Dong, J. et al. Dynamically regulated CFTR expression and its functional role in cutaneous wound healing. J Cell Physiol. 230, 2019-2058. (2015). 
medRxiv preprint doi: https://doi.org/10.1101/2020.06.02.20120469; this version posted June 5, 2020. The copyright holder for this preprint (which was not certified by peer review) is the author/funder, who has granted medRxiv a license to display the preprint in perpetuity. It is made available under a CC-BY-NC-ND 4.0 International license .

67. Zhou, Y. et al. Downregulation of CFTR is involved in the formation of hypertrophic scars. Biomed Res Int. 2020, ID9526289. https://doi.org,10.1155/2020/9526289. (2020).

68. Chen, J. et al. Epidermal CFTR suppresses MAPK/NF-kB to promote cutaneous would healing. Cell Physiol Biochem. 39, 2262-2274. (2016).

69. Hibuse, T., Maeda, N., Nagasawa, A. \& Funahashi, T. Aquaporins and glycerol metabolism. Biochim Biophys Acta. 1758, 1004-1011. (2006).

70. Meli, R., Pirozzi, C. \& Pelagalli, A. New perspectives on the potential role of aquaporins (AQPs) in the physiology of inflammation. Front Physiol. 9, 101.

Doi:10.3389/fphys.2018.00101. (2018).

71. Bernard, F. et al. Clues to epidermal cancer proneness revealed by reconstruction of DNA repair-deficient xeroderma pigmentosum in vitro. Proc Natl Acad Sci USA. 98, 78177822. (2001).

72. Pageon, H., Bakala, H., Monnier, V. M. \& Asselineau, D. Collagen glycation triggers the formation of aged skin in vitro. Eur J Dermatol. 17, 12-20. (2007).

73. Chen, Y. E., Fischbach, M. A. \& Belkaid, Y. Skin microbiota-host interactions. Nature. 553, 427-436. (2018).

74. Belkaid, Y. \& Tamoutounour, S. The influence of skin microorganisms on cutaneous immunity. Nat Rev Immunol. 16, 353-366. (2016).

75. McDonald, D. et al. American Gut: an open platform for citizen science microbiome research. mSystems. 3, e00031-18. https://doi.org/10.1128/mSystems.00031-18. (2018).

76. Brandwein, M., Katz, I., Katz, A. \& Kohen, R. Beyond the gut: skin microbiome compositional changes are associated with BMI. Hum Microbiome J. 13, 100063. https://doi.org/10.1016/j.humic.2019.100063 (2019). 
medRxiv preprint doi: https://doi.org/10.1101/2020.06.02.20120469; this version posted June 5, 2020. The copyright holder for this preprint

(which was not certified by peer review) is the author/funder, who has granted medRxiv a license to display the preprint in perpetuity.

It is made available under a CC-BY-NC-ND 4.0 International license.

77. Vongsa, R., Hoffman, D., Shepard, K. \& Koenig, D. Comparative study of vulva and abdominal skin microbiota of healthy females with high and average BMI. $B M C$

Microbiol. 19, 16. https://doi.org/10.1189/s12866-019-1319-0. (2019).

78. Rood, K. M. et al. Skin microbiota in obese women at risk for surgical site infection after caesarean section delivery. Sci Rep. 8:8756 Doi:10/1038/s41598-018-28134-5. (2018).

79. Oh, J. et al. Biogeography and individuality shapes function in the human skin metagenome. Nature. 514, 59-64. (2014).

80. Agrawal, K., Sivanami, R. K. \& Newman, J. W. Non-invasive profiling of sweat-derived lipid mediators for cutaneous research. Skin Res Technol. 25, 3-11. (2018). 
medRxiv preprint doi: https://doi.org/10.1101/2020.06.02.20120469; this version posted June 5, 2020. The copyright holder for this preprint (which was not certified by peer review) is the author/funder, who has granted medRxiv a license to display the preprint in perpetuity.

It is made available under a CC-BY-NC-ND 4.0 International license .

\section{Figure 1}

\section{CONSORT FLOW CHART}

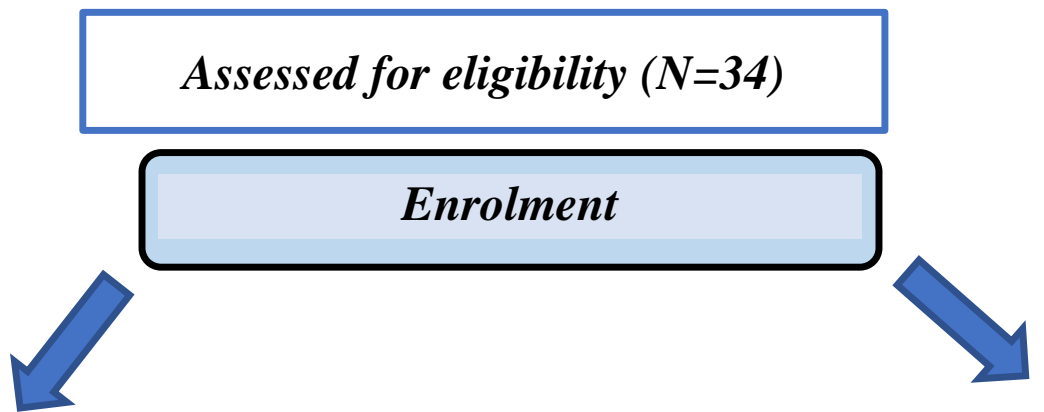

Obese Group $n=14$

\section{non-obese $n=20$}

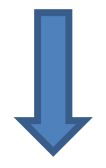

Excluded: $n=2$

1 taking celecoxib $\mathrm{Rx}$

1 not postmenopausal for 24

months

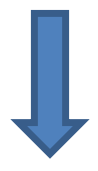

Subjects on study: $n=12$

2 subjects refused skin biopsy

Subjects completing skin swabs and biopsy $n=10$
Excluded: $n=7$

1 for illness

1 withdrew consent

2 BMI too high

1 uncontrolled hypertension

1 keloids

1 low platelet count

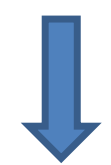

Analysed $(n=10)$

- 6 Caucasians

- 4 African Americans

Excluded from analysis $(n=0)$

\section{Follow-Up}

Subjects on study: $n=13$

2 subjects refused skin biopsy

Subjects completing skin swab and biopsy: $n=11$

1 subject excluded due to inability to match 
medRxiv preprint doi: https://doi.org/10.1101/2020.06.02.20120469; this version posted June 5, 2020. The copyright holder for this preprint (which was not certified by peer review) is the author/funder, who has granted medRxiv a license to display the preprint in perpetuity.

It is made available under a CC-BY-NC-ND 4.0 International license .

Figure 2

Caucasian

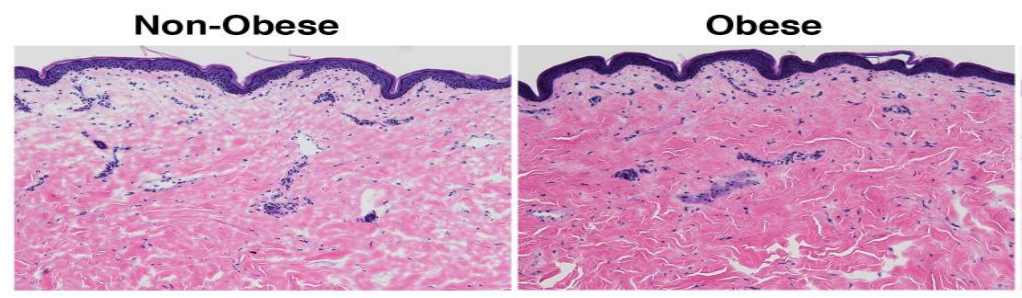

African-American

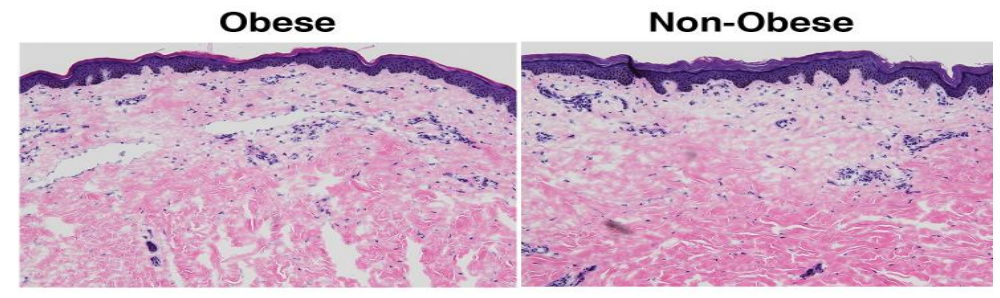

Epidermal Thickness in Obese and Non-Obese Subjects
$n$
Mean
$+/-\mathrm{SD}$
$p=$

\section{microns}

Obese

10

45.1

11.5

0.512

Non-Obese

10

41.8

9.8

Obese and non-obese

African Americans

8

48.4

7.9

0.086

Obese and non-obese

Caucasians

12

40.1

11.1

Epidermal thickness measured as microns, mean +/-SD, and difference ( $\mathrm{p}$ values) in the number (n) of obese and non-obese subjects; obese and non-obese and African American subjects and obese and non-obese Caucasian subjects is shown. 
medRxiv preprint doi: https://doi.org/10.1101/2020.06.02.20120469; this version posted June 5, 2020. The copyright holder for this preprint (which was not certified by peer review) is the author/funder, who has granted medRxiv a license to display the preprint in perpetuity.

It is made available under a CC-BY-NC-ND 4.0 International license .

\section{Figure 3 SKIN: Obese vs. Non-Obese}

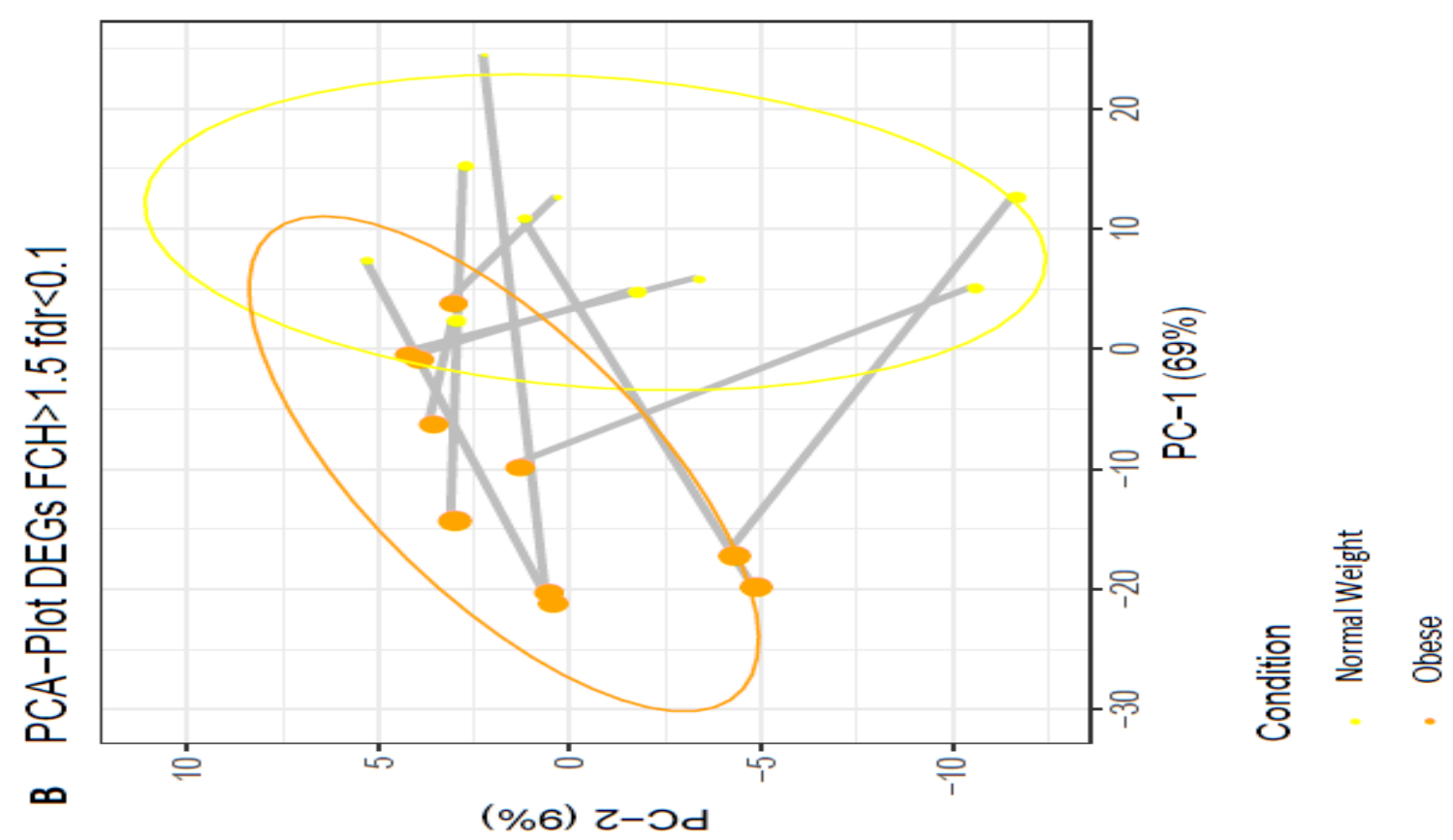

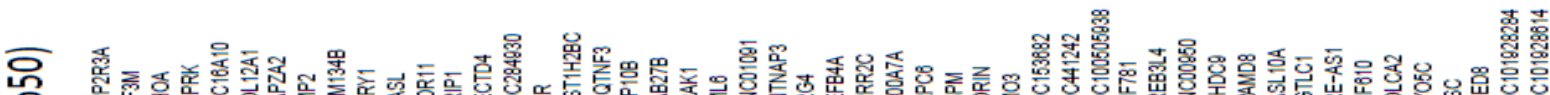

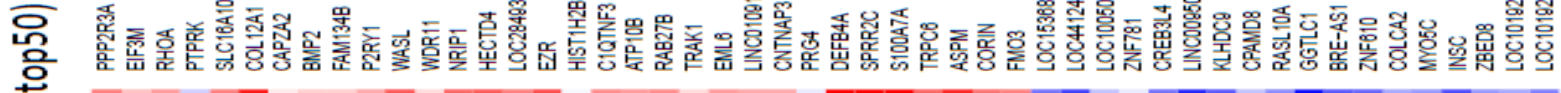

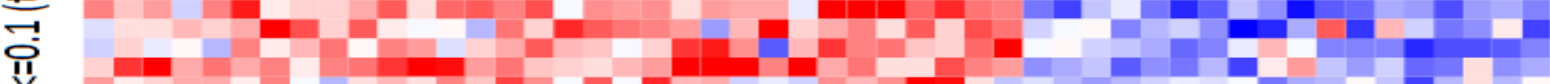

䔬

논

손

$\ddot{\boldsymbol{\omega}}$

产

용

ळ

흔

빰

要

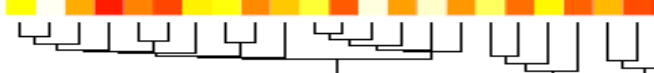

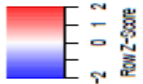

$\leftarrow$ 
medRxiv preprint doi: https://doi.org/10.1101/2020.06.02.20120469; this version posted June 5, 2020. The copyright holder for this preprint (which was not certified by peer review) is the author/funder, who has granted medRxiv a license to display the preprint in perpetuity.

It is made available under a CC-BY-NC-ND 4.0 International license .

\section{Figure 4}

SKIN: Obese vs Non-Obese
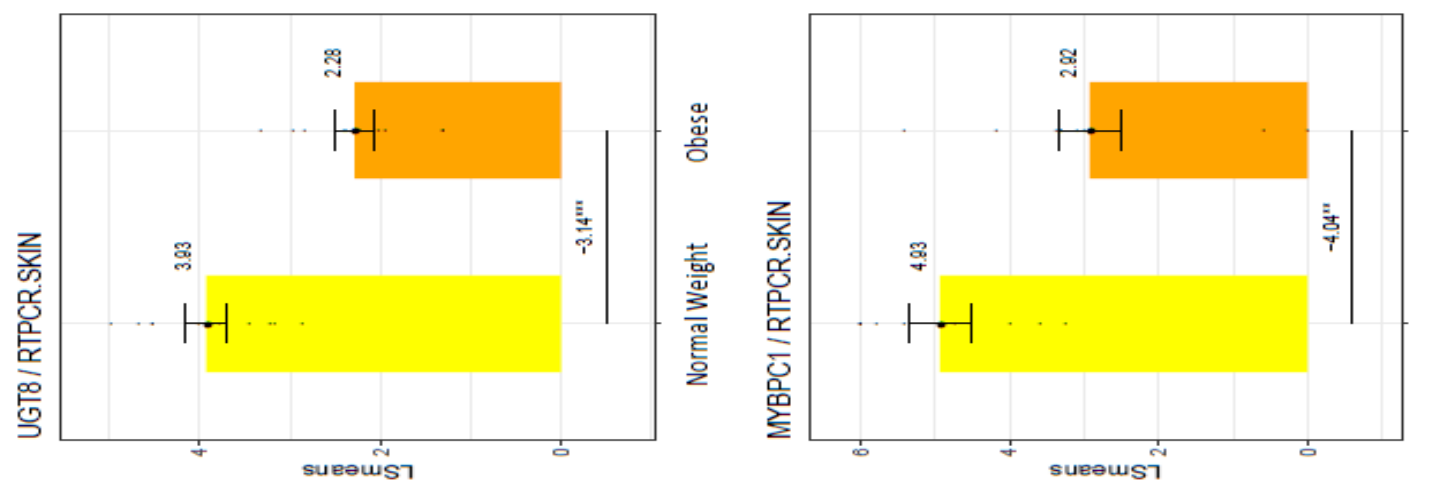

ัั
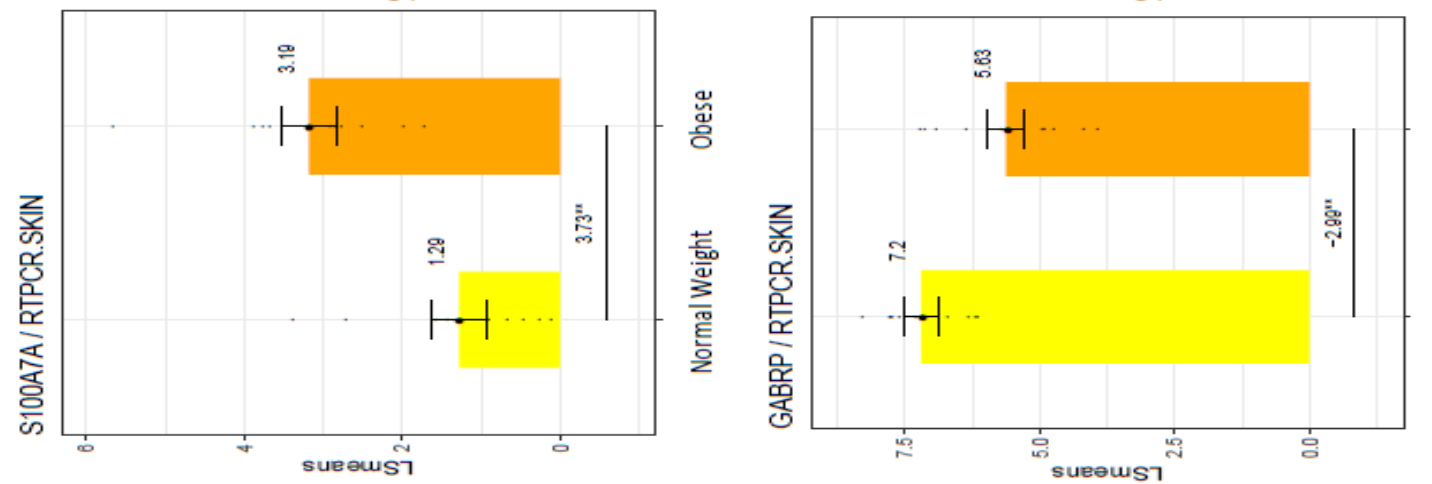

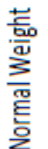
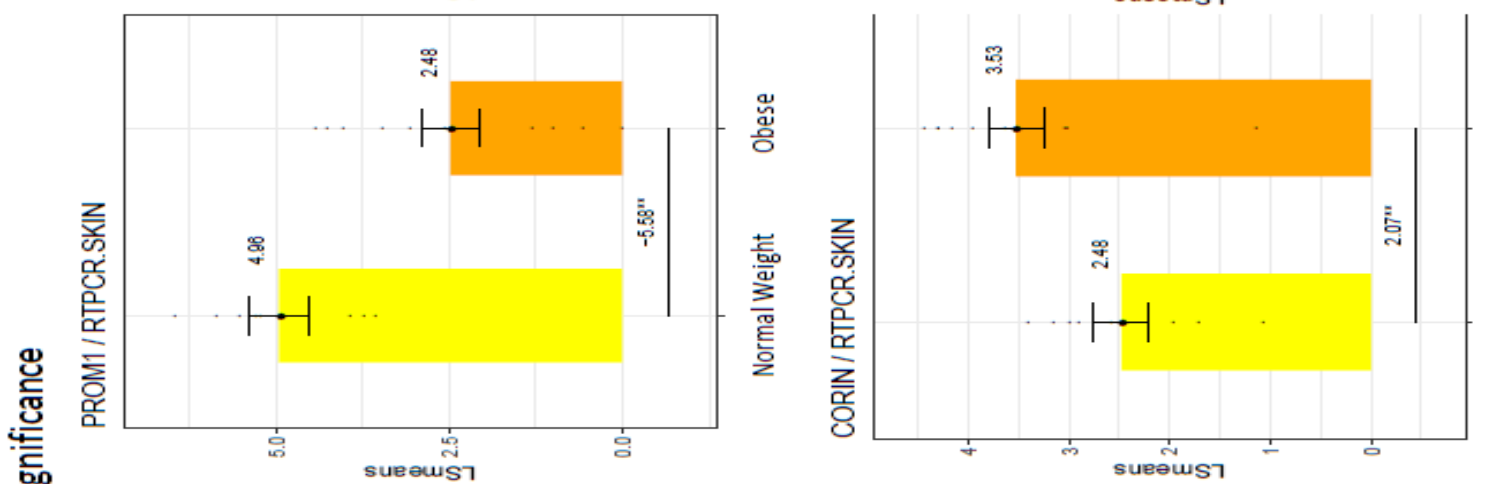

ัั

苂

萬

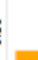

$1-1$
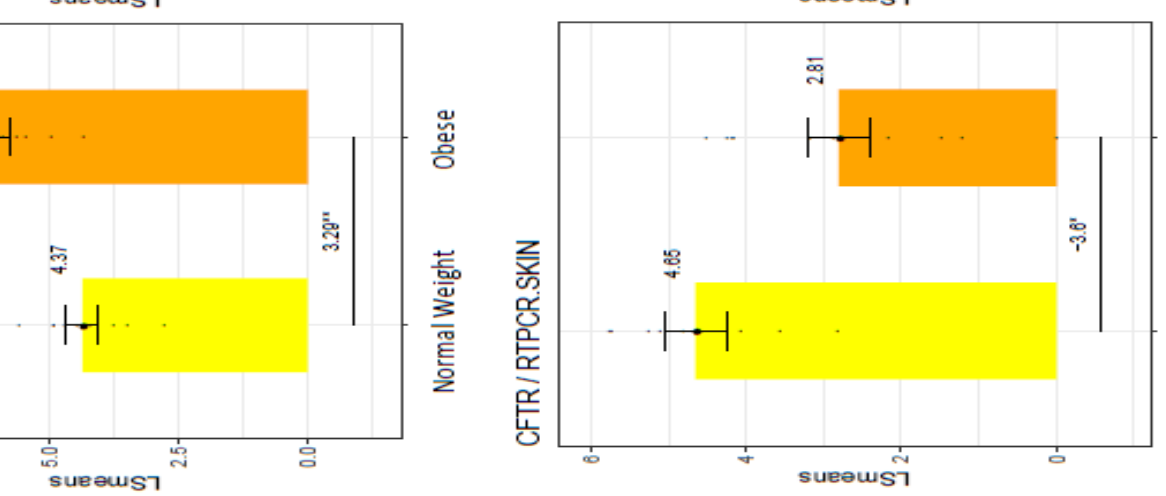

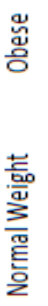


medRxiv preprint doi: https://doi.org/10.1101/2020.06.02.20120469; this version posted June 5, 2020. The copyright holder for this preprint (which was not certified by peer review) is the author/funder, who has granted medRxiv a license to display the preprint in perpetuity.

It is made available under a CC-BY-NC-ND 4.0 International license.

\section{Figure 5}

\section{SKIN}

\section{Obese vs. Non-Obese}

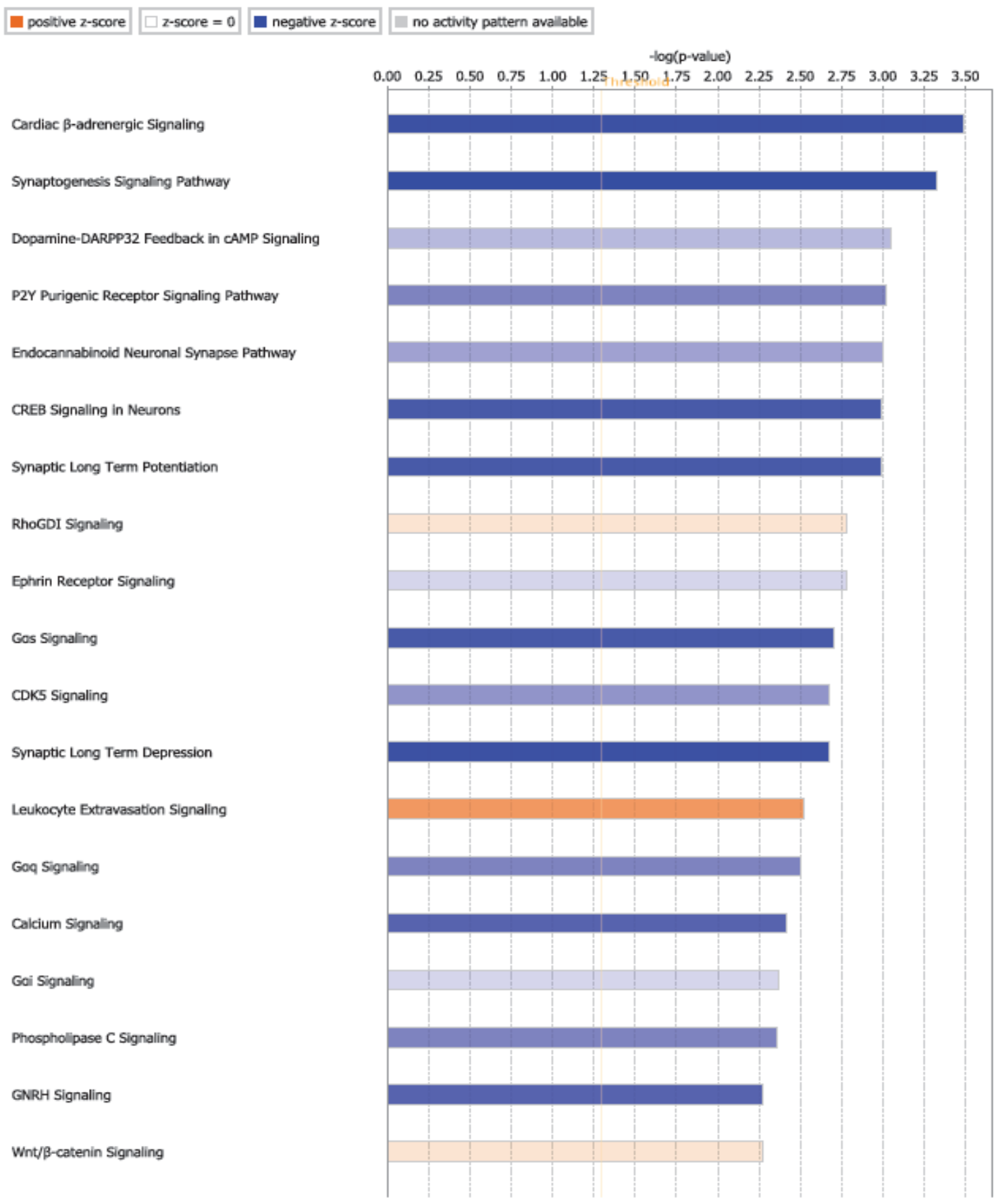




\section{Figure 6}

\section{FAT: Obese vs. Non-Obese}
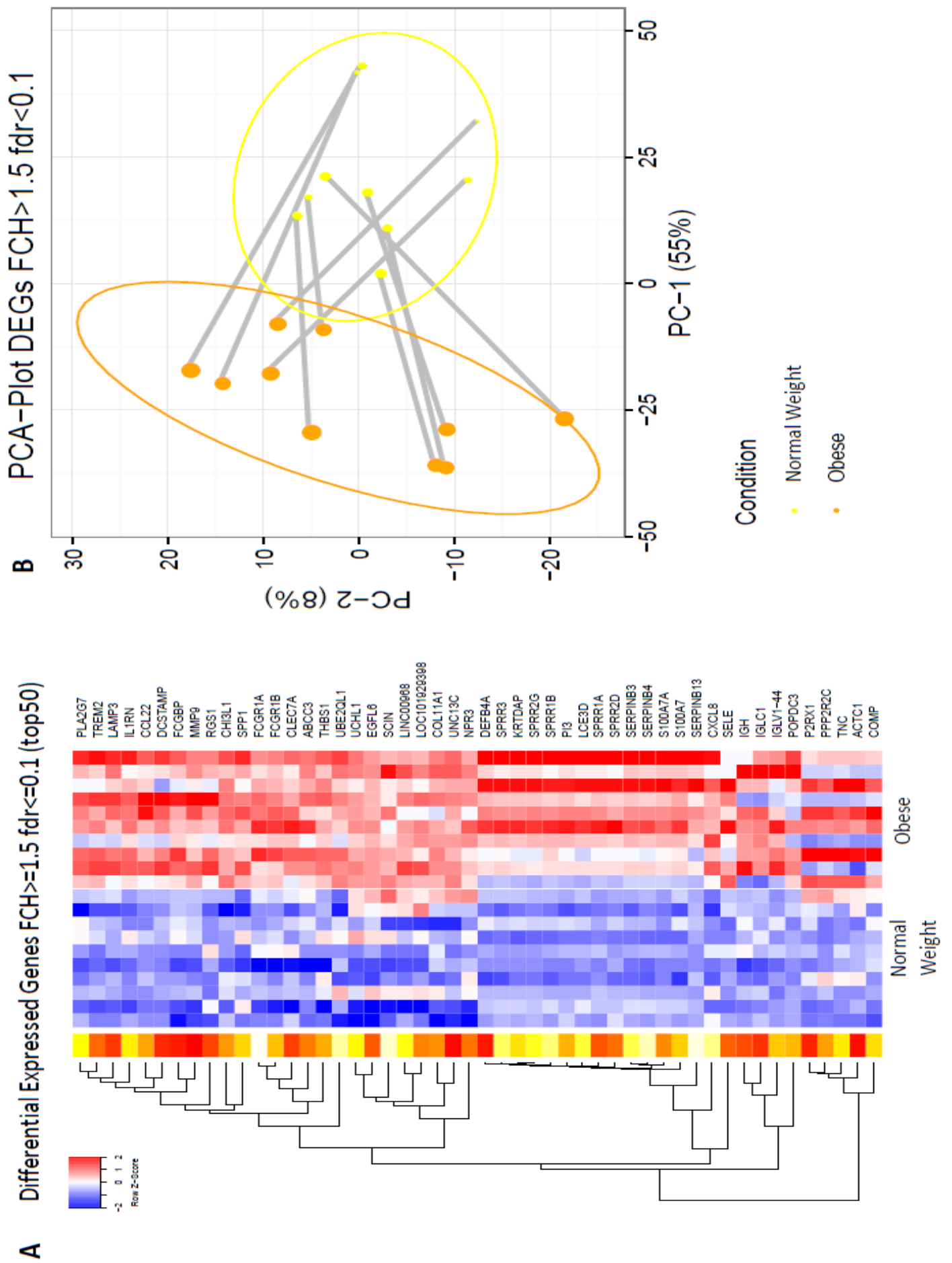

安 
medRxiv preprint doi: https://doi.org/10.1101/2020.06.02.20120469; this version posted June 5, 2020. The copyright holder for this preprint (which was not certified by peer review) is the author/funder, who has granted medRxiv a license to display the preprint in perpetuity.

It is made available under a CC-BY-NC-ND 4.0 International license .

\section{Figure 7}

\section{FAT: Obese vs. Non-Obese}
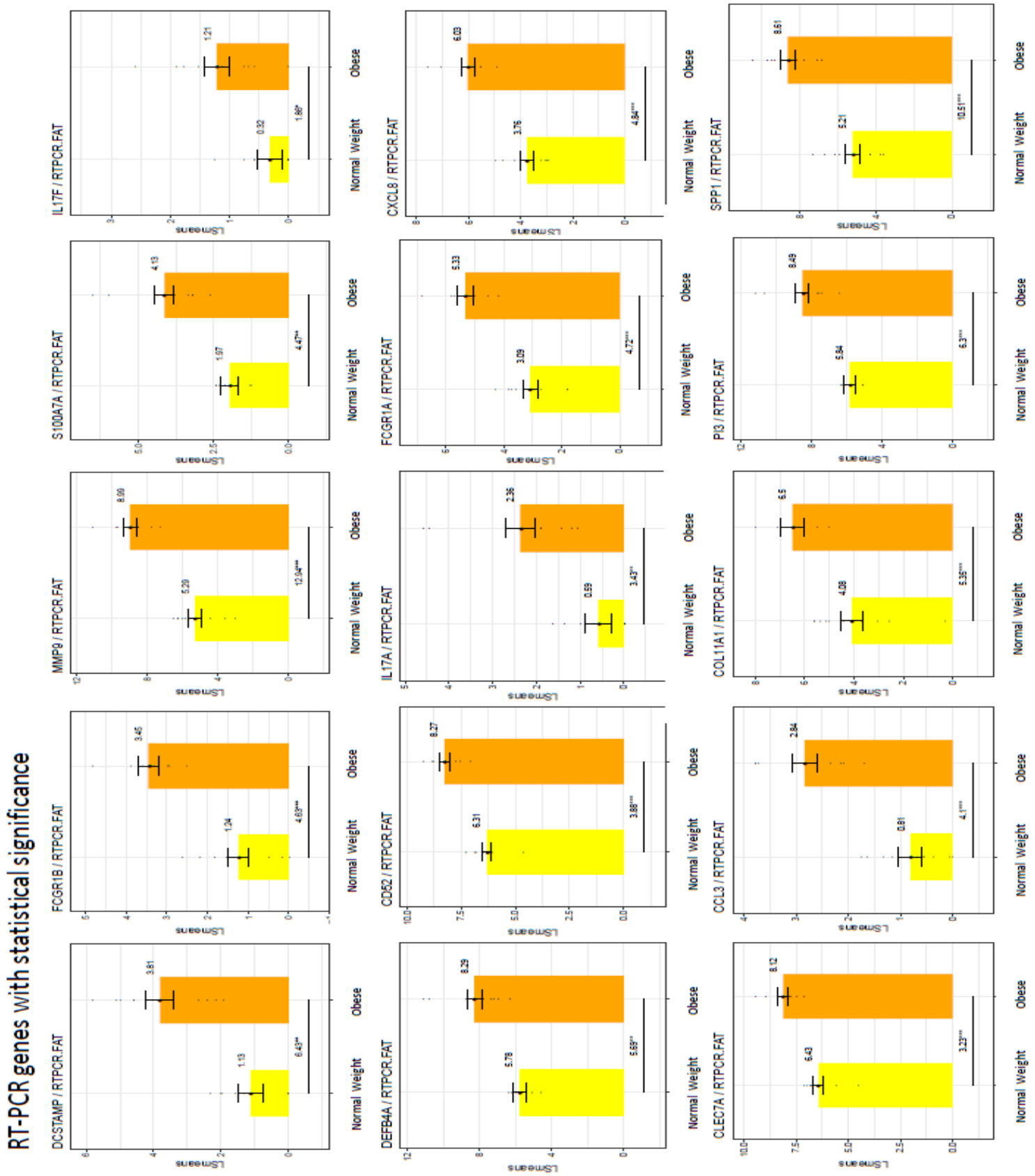

壹 
medRxiv preprint doi: https://doi.org/10.1101/2020.06.02.20120469; this version posted June 5, 2020. The copyright holder for this preprint (which was not certified by peer review) is the author/funder, who has granted medRxiv a license to display the preprint in perpetuity.

It is made available under a CC-BY-NC-ND 4.0 International license .

\section{Figure 8}

\section{FAT: Obese vs. Non-Obese}

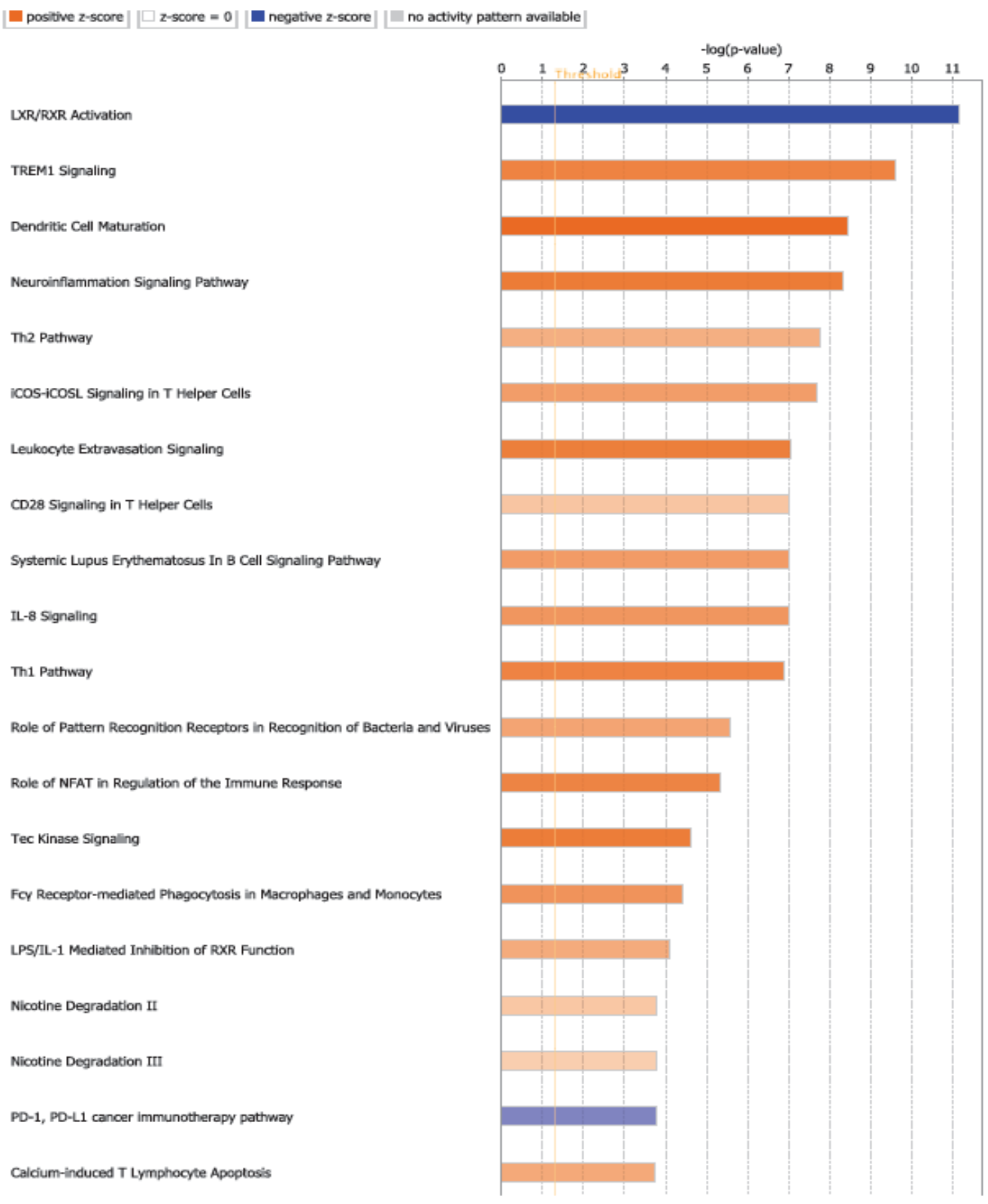


medRxiv preprint doi: https://doi.org/10.1101/2020.06.02.20120469; this version posted June 5, 2020. The copyright holder for this preprint (which was not certified by peer review) is the author/funder, who has granted medRxiv a license to display the preprint in perpetuity.

It is made available under a CC-BY-NC-ND 4.0 International license .

\section{Figure 9}

\section{SKIN: African American vs. Caucasian}

$\infty$

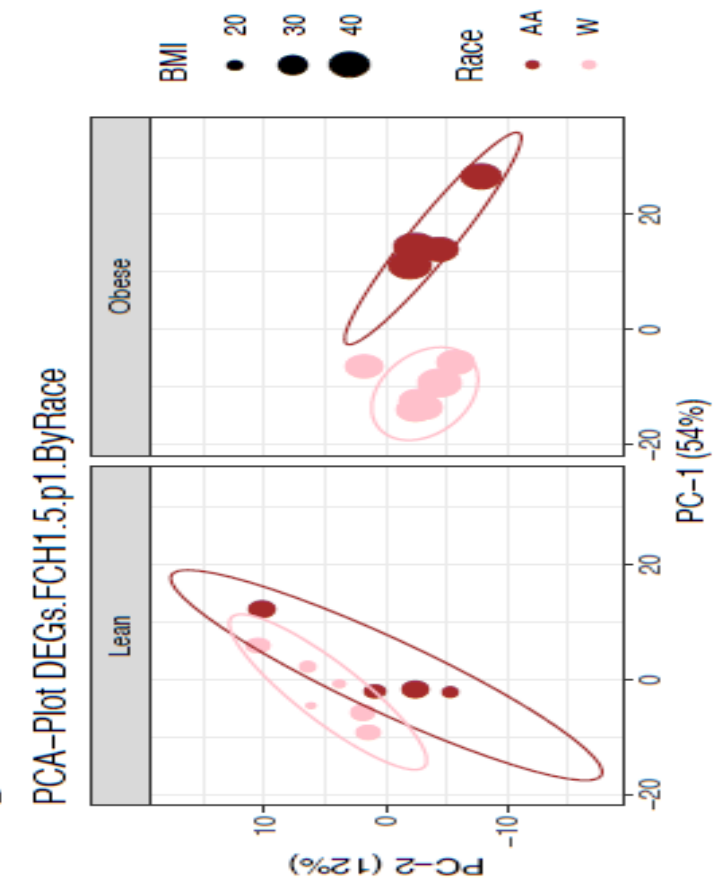

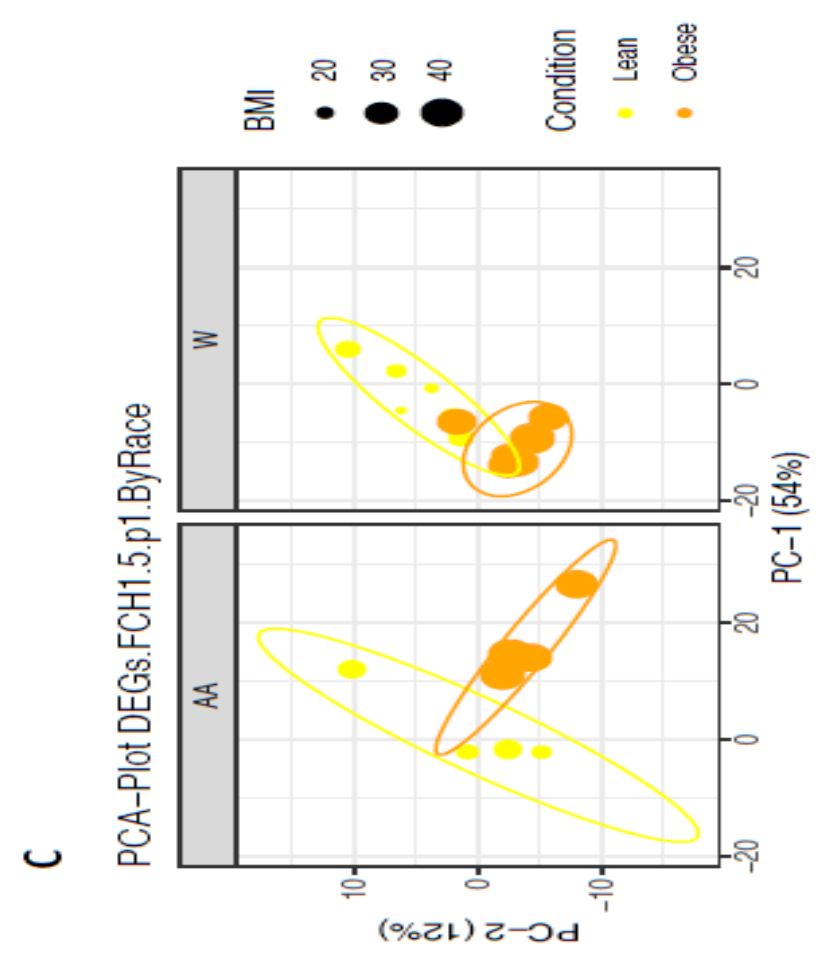

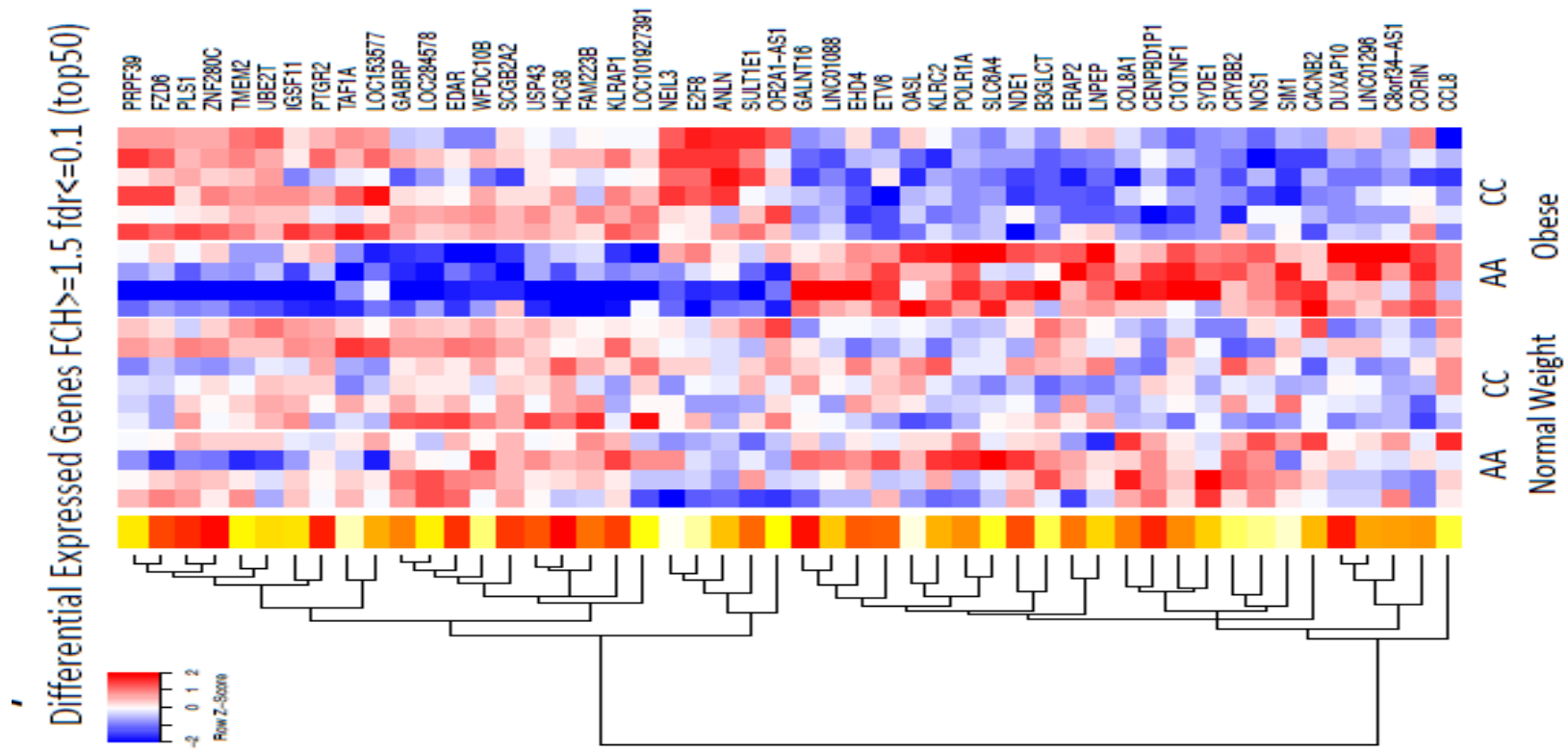


medRxiv preprint doi: https://doi.org/10.1101/2020.06.02.20120469; this version posted June 5, 2020. The copyright holder for this preprint (which was not certified by peer review) is the author/funder, who has granted medRxiv a license to display the preprint in perpetuity.

It is made available under a CC-BY-NC-ND 4.0 International license .

\section{Figure 10}

\section{SKIN: African American vs. Caucasian}
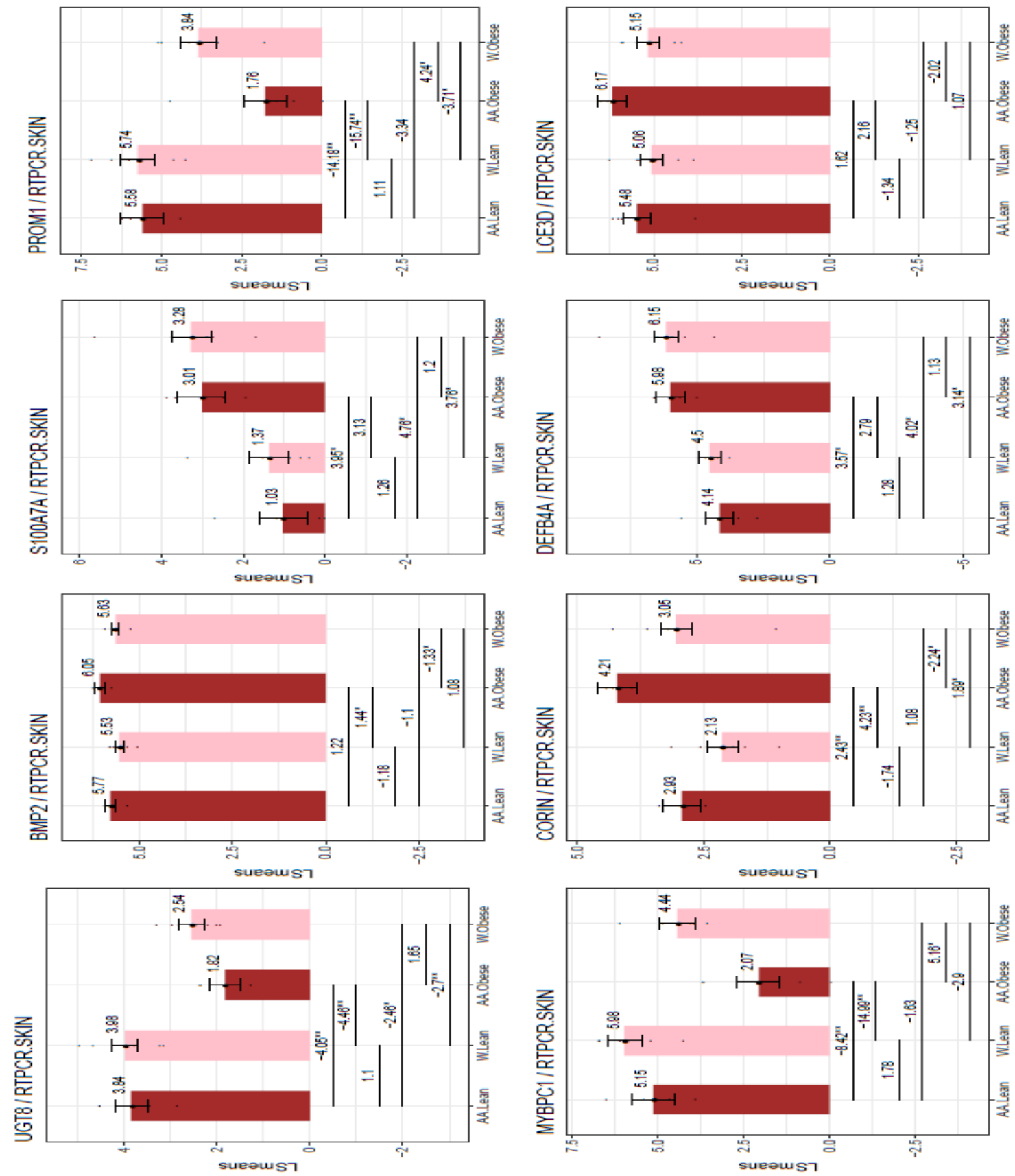

\section{롷 产}


medRxiv preprint doi: https://doi.org/10.1101/2020.06.02.20120469; this version posted June 5, 2020. The copyright holder for this preprint (which was not certified by peer review) is the author/funder, who has granted medRxiv a license to display the preprint in perpetuity.

It is made available under a CC-BY-NC-ND 4.0 International license .

\section{Figure 11}

\section{SKIN: Obese African American vs Caucasian}

positive $z$-score $\square$ z-score $=0 \quad \square$ negative $z$-score $\square$ no activity pattern available

Estrogen-mediated S-phase Entry

Aryl Hydrocarbon Receptor Signaling

Cyclins and Cell Cycle Regulation

Cell Cycle Regulation by BTG Family Proteins

Role of BRCA1 in DNA Damage Response

Aldosterone Signaling in Epithelial Cells

HGF Signaling

Cell Cycle: G1/S Checkpoint Regulation

Production of Nitric Oxide and Reactive Oxygen Species in Macrophages

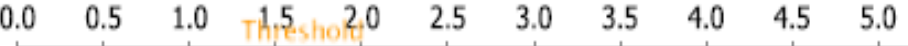

(c) 2000-2019 QIACEN. All rights reserved. 
medRxiv preprint doi: https://doi.org/10.1101/2020.06.02.20120469; this version posted June 5, 2020. The copyright holder for this preprint (which was not certified by peer review) is the author/funder, who has granted medRxiv a license to display the preprint in perpetuity.

It is made available under a CC-BY-NC-ND 4.0 International license .

\section{Figure 12}

\section{FAT: African American vs Caucasian}
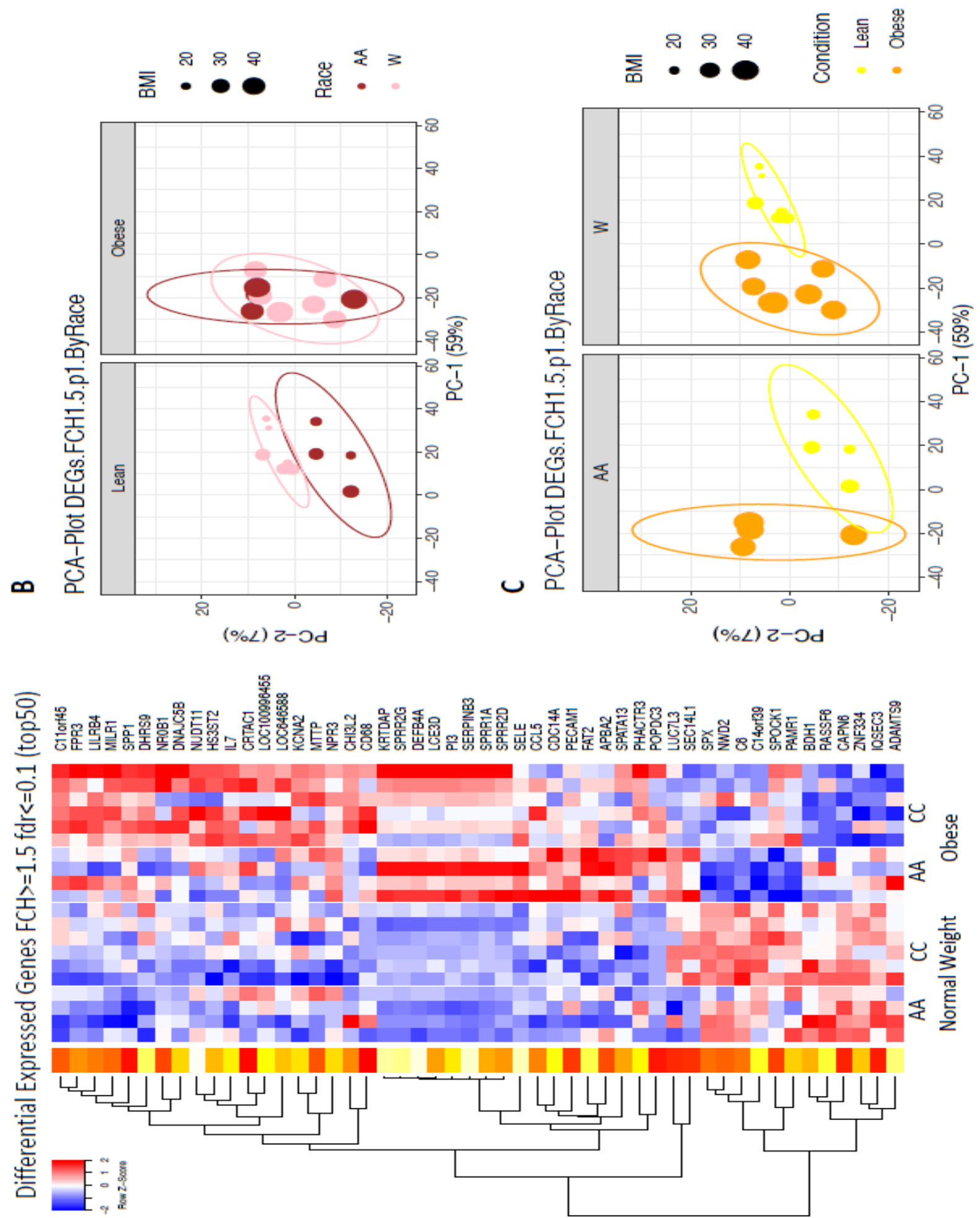

$<$ 
medRxiv preprint doi: https://doi.org/10.1101/2020.06.02.20120469; this version posted June 5, 2020. The copyright holder for this preprint (which was not certified by peer review) is the author/funder, who has granted medRxiv a license to display the preprint in perpetuity.

It is made available under a CC-BY-NC-ND 4.0 International license .

\section{Figure 13}

\section{FAT: African American vs. Caucasian}
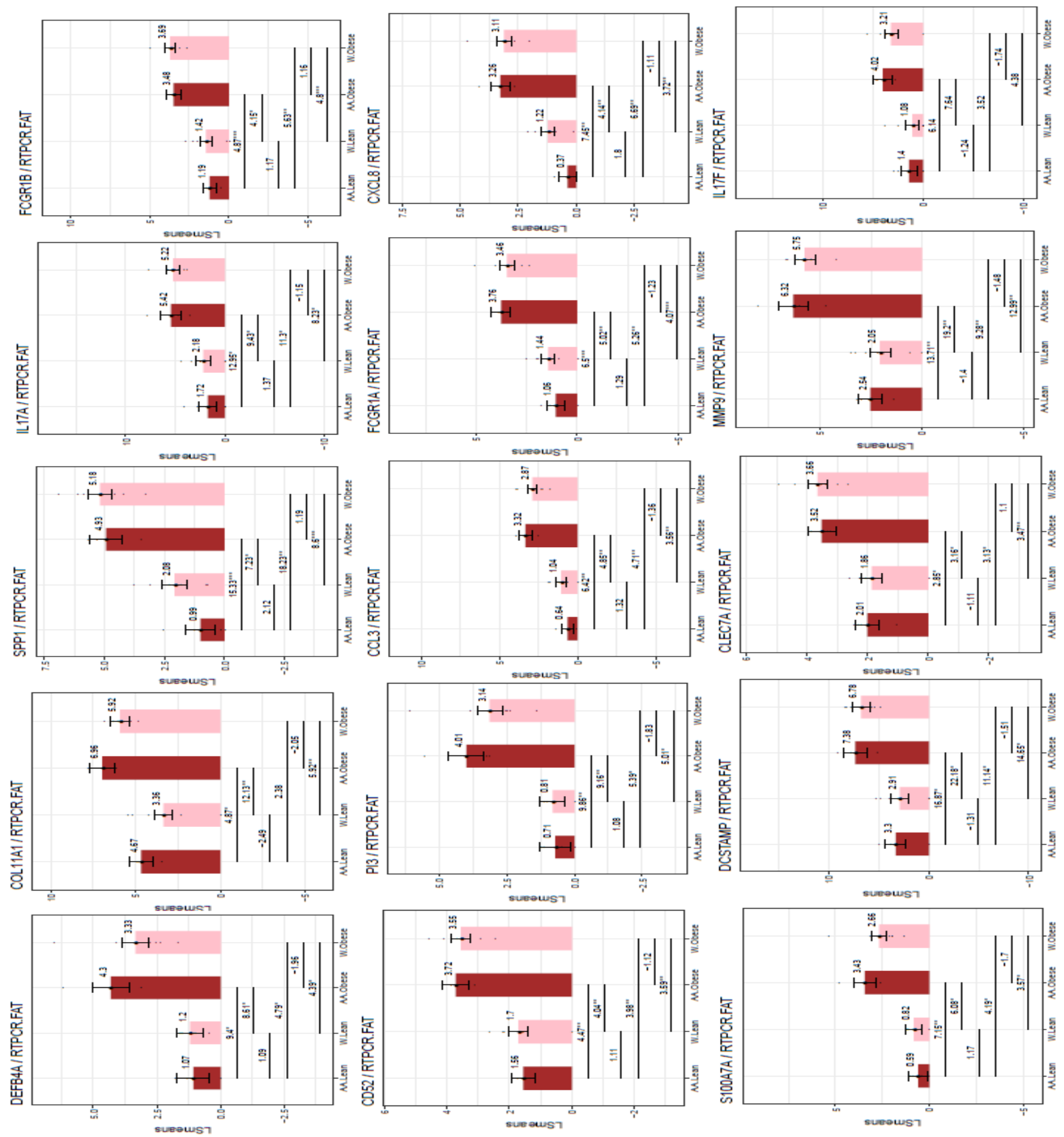

\section{透䒿}


medRxiv preprint doi: https://doi.org/10.1101/2020.06.02.20120469; this version posted June 5, 2020. The copyright holder for this preprint (which was not certified by peer review) is the author/funder, who has granted medRxiv a license to display the preprint in perpetuity.

It is made available under a CC-BY-NC-ND 4.0 International license .

\section{Figure 14}

\section{FAT: Obese African American vs. Caucasian}

$\square$ positive $\mathrm{z}$-score $\square$ z-score $=0 \quad \square$ negative $\mathrm{z}$-score $\square$ no activity pattern available

fMLP Signaling in Neutrophils

D-myo-inositol $(1,4,5,6)$-Tetrakisphosphate Biosynthesis

D-myo-inositol (3,4,5,6)-tetrakisphosphate Biosynthesis

3-phosphoinositide Degradation

Systemic Lupus Erythematosus In B Cell Signaling Pathway

D-myo-inositol-5-phosphate Metabolism

LPS/IL-1 Mediated Inhibition of RXR Function

3-phosphoinositide Biosynthesis

Neuroinflammation Signaling Pathway

Superpathway of Inositol Phosphate Compounds

(c) 2000-2019 QIACEN. All rights reserved.

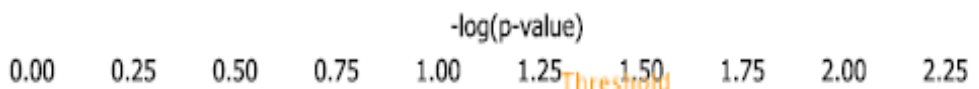




\section{Figure 15}

\section{Metagenomic analysis of skin microbiomes}

\section{Beta Diversity}

A

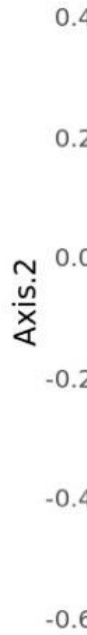

0.6

0.2

0.4
Axis.1

Weight

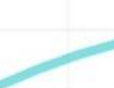

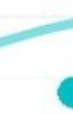

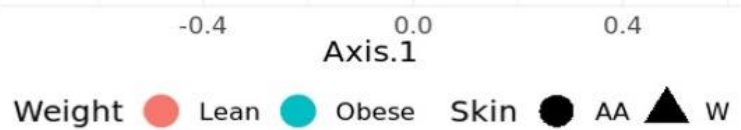

B
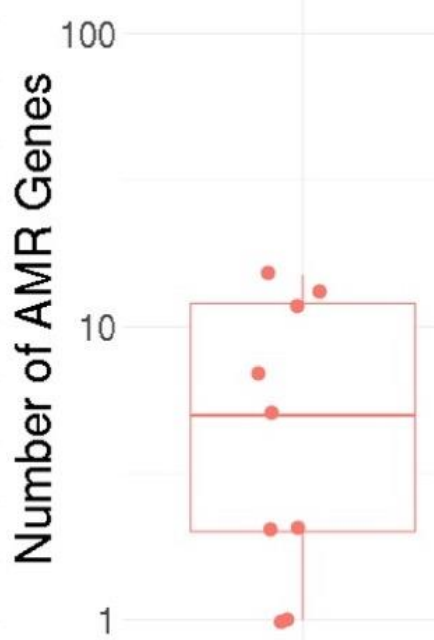

-
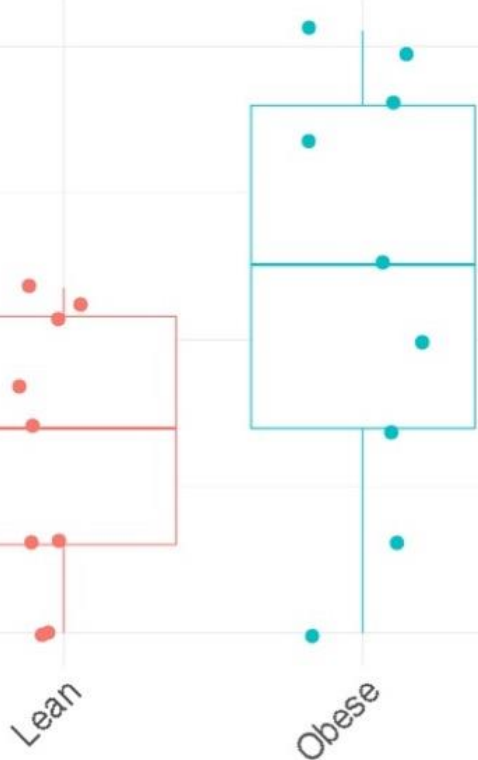


\section{Figure Legends}

\section{Figure 1}

Consort flow chart of eligible subjects

\section{Figure 2}

A. Typical photomicrograph of skin biopsies from obese and non-obese subjects and from African American and Caucasian subjects

Paired by age and skin colour

B. Dimensions of the epidermis of obese and non-obese African American and Caucasian subjects.

Note no difference in epidermal thickness between obese and non-obese subjects but a trend to a wider epidermis in African Americans than in Caucasian subjects.

\section{Figure 3}

Differences in gene expression between the skin of obese and non-obese subjects

A. Heat map of the 50 most differentially expressed genes in the skin of obese and nonobese subjects with an FCH (fold change) $>=1.551$; fdr (false discovery rate) $<=0.1$

B. PCA (principal component analysis) plot of differentially expressed genes in the skin of obese and non-obese subjects with an $\mathrm{FCH}>=1.5$; $\mathrm{fdr}<0.1$

\section{Figure 4}

Differences in gene expression by RT- PCR between the skin of obese and non-obese subjects. LS means of gene expression by RT-PCR showing significant differences as * $p<0.05$;

$* * p<0.01 ; * * * p<0.001$

\section{Figure 5}

Gene expression pathway analysis between the skin of obese and non-obese subjects. 
Data shown from analysis of all differentially expressed genes.

Log value shown in blue $=$ negative $z$ score

Log value shown in orange $=$ positive $z$ score

\section{Figure 6}

Differences in gene expression between the subdermal fat of obese and non-obese subjects

A. Heat map of the 50 most differentially expressed genes in subdermal fat of obese and non-obese subjects with an $\mathrm{FCH}>=1.5 ; \mathrm{fdr}<0.1$

B. PCA plot of differentially expressed genes in subdermal fat of obese and non-obese subjects with an $\mathrm{FCH}>=1.5 ; \mathrm{fdr}<0.1$

\section{Figure 7}

Differences in gene expression by RT- PCR between the subdermal fat of obese and non-obese subjects.

LS means of gene expression by RT-PCR showing significant differences as ${ }^{*} p<0.05$;

$* * p<0.01 ; * * * p<0.001$

\section{Figure 8}

Gene expression pathway analysis between the subdermal fat of obese and non-obese subjects.

Data shown from analysis of all differentially expressed genes.

Log value shown in blue $=$ negative $z$ score

Log value shown in orange $=$ positive $z$ score .

\section{Figure 9}

Differences in gene expression between the skin of African American and Caucasian subjects

A. Heat map of the 50 most differentially expressed genes in skin of African American and Caucasian subjects with an $\mathrm{FCH}>=1.5 ; \mathrm{fdr}<=0.1$ 
B. PCA plot of differentially expressed genes in skin of obese and non-obese African American and Caucasian subjects with an $\mathrm{FCH}=1.5$.

Left side of plot indicates differences in gene expression by race in non-obese subjects. Right side of plot indicates differences in gene expression by race in obese subjects.

C. PCA plot of differentially expressed genes in skin of obese and non-obese subjects by race with an $\mathrm{FCH}=1.5$.

Left side of plot indicates differences in gene expression between obese and non-obese African American subjects.

Right side of plot indicates differences in gene expression between obese and non-obese Caucasian subjects.

\section{Figure 10}

Differences in gene expression by RT- PCR between the skin of obese and non-obese African American and Caucasian subjects.

LS means of gene expression by RT-PCR showing significant differences as $* p<0.05$; $* * p<0.01 ; * * * p<0.001$.

\section{Figure 11}

Gene expression pathway analysis between the skin of obese African American and obese Caucasian subjects.

Data shown from analysis of all differentially expressed genes.

Log value shown in blue $=$ negative $z$ score

Log value shown in orange $=$ positive $z$ score

\section{Figure 12}


medRxiv preprint doi: https://doi.org/10.1101/2020.06.02.20120469; this version posted June 5, 2020. The copyright holder for this preprint

(which was not certified by peer review) is the author/funder, who has granted medRxiv a license to display the preprint in perpetuity.

It is made available under a CC-BY-NC-ND 4.0 International license .

Differences in gene expression between the subdermal fat of African American and Caucasian subjects

A. Heat map of the 50 most differentially expressed genes in subdermal fat of African

American and Caucasian subjects with an $\mathrm{FCH}>=1.5 ; \mathrm{fdr}<=0.1$

B. PCA plot of differentially expressed genes in subdermal fat of obese and non-obese

African American and Caucasian subjects with an $\mathrm{FCH}=1.5$.

Left side of plot indicates differences in gene expression by race in non-obese subjects.

Right side of plot indicates differences in gene expression by race in obese subjects.

C. PCA plot of differentially expressed genes in subdermal fat of obese and non-obese subjects by race with an $\mathrm{FCH}=1.5$.

Left side of plot indicates differences in gene expression in obese and non-obese African American subjects.

Right side of plot indicates differences in gene expression in obese and non-obese Caucasian subjects.

\section{Figure 13}

Differences in gene expression by RT- PCR between the subdermal fat of obese and non-obese African American and obese and non-obese Caucasian subjects.

LS means of gene expression by RT-PCR showing significant differences as ${ }^{*} p<0.05$;

$* * p<0.01 ; * * * p<0.001$.

\section{Figure 14}

Gene pathway analysis between the subdermal fat of obese African American and obese

Caucasian subjects.

Data shown from analysis of all differentially expressed genes. 
medRxiv preprint doi: https://doi.org/10.1101/2020.06.02.20120469; this version posted June 5, 2020. The copyright holder for this preprint (which was not certified by peer review) is the author/funder, who has granted medRxiv a license to display the preprint in perpetuity. It is made available under a CC-BY-NC-ND 4.0 International license.

Log value shown in blue $=$ negative $z$ score

Log value shown in orange $=$ positive $z$ score

\section{Figure 15}

Metagenomic analysis of skin microbiomes

A. PCA plot of taxonomic profiles for skin microbiomes from obese and non-obese subjects

B. Total number of Antimicrobial Resistance Genes detected in samples ( $p=0.1$; Wilcox test). 
medRxiv preprint doi: https://doi.org/10.1101/2020.06.02.20120469; this version posted June 5, 2020. The copyright holder for this preprint (which was not certified by peer review) is the author/funder, who has granted medRxiv a license to display the preprint in perpetuity.

It is made available under a CC-BY-NC-ND 4.0 International license .

\section{Supplemental Materials}

Methods

Skin microbiome: The DNA extraction protocol was adapted from the Maxwell RSC Buccal Swab DNA kit (Catalogue number AS1640: Promega Corporation, Madison WI). Briefly, 300 $\mu \mathrm{l}$ of lysis buffer and $30 \mu \mathrm{l}$ of Proteinase K was mixed and added to each swab tube. Swab tubes were then incubated for 20 minutes at $56 \mathrm{C}$ using a Thermo Fisher water bath, removed from the tubes, and fluid was transferred to well \#1 of the Maxwell RSC Cartridge. The swab head was centrifuged using a ClickFit Microtube (Cat. \# V4741), and extracted fluid was added to the corresponding well of Maxwell Cartridge, and eluted in $50 \mu \mathrm{l}$ of provided elution buffer.

Extracted DNA was taken forward to the Nextera Flex protocol by Illumina. Briefly, $30 \mu \mathrm{l}$ of extracted DNA was taken into library prep protocol and run with 12 cycles of PCR. Libraries were cleaned up with a left sided size selection, using a bead ratio of $0.8 x$. The right sided size selection was omitted. Libraries were then quantified using a Thermo Fisher Qubit Fluorometer and an Advanced Analytical Fragment Analyzer. Libraries were sequenced on an Illumina HiSeqPE 50x2 at the Weill Cornell Epigenomics Core.

All bioinformatic analysis was performed on Weill Cornell Medicine's Athena compute cluster, a high-performance grid compute system. Secondary analysis was performed on a Linux and MacOS systems. Unless otherwise noted programs were run with default settings.

Raw sequence data were processed with AdapterRemoval (v2.17) to remove low quality reads and reads with ambiguous bases [S1]. Subsequently reads were aligned to the human genome (hg38, including alternate contigs) using Bowtie2 (v2.3.0, fast preset) [S2]. Read pairs where one or both ends mapped to the human genome were separated from read pairs where 
medRxiv preprint doi: https://doi.org/10.1101/2020.06.02.20120469; this version posted June 5, 2020. The copyright holder for this preprint (which was not certified by peer review) is the author/funder, who has granted medRxiv a license to display the preprint in perpetuity.

It is made available under a CC-BY-NC-ND 4.0 International license .

neither mate mapped. Read pairs where only one mate mapped were discarded. Hereafter, we refer to the read sets as human reads and non-human reads.

Taxonomic profiles were generated by processing non-human reads with KrakenUniq (v0.3.2) with a database based on all draft and reference genomes in RefSeq Microbial (bacteria, fungi, virus, and archaea) ca. March 2017. KrakenUniq identifies k-mers that are unique to taxa in a database. Reads are broken into k-mers and searched against this database. Finally, the taxonomic makeup of each sample was given by taking the proportion reads which were assigned to each clade. KrakenUniq counts the number of unique marker k-mers assigned to each taxon and we filtered taxa with fewer than 512 unique markers [S3].

We performed differential abundance testing over microbial species using the ALDEx2 R package. ALDEx2 performs variance stabilization read counts using a centred log ratio transformation that models samples as Dirichlet-Multinomial distributions over taxa then compares taxonomic abundances across groups [S4]. Comparison of abundances across groups was done with a Wilcoxon rank sum test and Benjamini Hochberg Correction for multiple hypothesis testing.

Dimensionality reduction of taxonomic profiles was performed with Principal Coordinates Analysis based on a matrix of Jensen-Shannon Divergences (JSD) between samples. Analysis of inter-sample (beta) diversity was performed using the same matrix of JSD. Intrasample (alpha) diversity was measured by finding Shannon's Entropy of the taxonomic profile and by counting the total number of species identified in each sample (richness). Shannon's entropy accounts for the relative size of each group in diversity estimation and is defined as $H=$ $-\sum a_{i} \log _{2} a_{i}$ where $a_{i}$ is the relative abundance of taxa $i$ in the sample. 
medRxiv preprint doi: https://doi.org/10.1101/2020.06.02.20120469; this version posted June 5, 2020. The copyright holder for this preprint (which was not certified by peer review) is the author/funder, who has granted medRxiv a license to display the preprint in perpetuity. It is made available under a CC-BY-NC-ND 4.0 International license .

We generated profiles of antimicrobial resistance genes using MegaRes (v1.0.1) [S5]. To generate profiles from MegaRes, we mapped non-human reads to the database using Bowtie2 (v2.3.0, very sensitive presets). Subsequently, alignments were analysed using Resistome Analyzer (commit 15a52dd) and normalized by total reads per sample and gene length to give RPKMs. MegaRes includes an ontology grouping resistance genes into gene classes, AMR mechanisms, and gene groups.

Skin metabolome: The skin was swabbed using two sterile, saline-moistened culture swabs and immediately frozen at $-80^{\circ} \mathrm{C}$. Swab heads were removed and placed in $1 \mathrm{~mL}$ methanol: water (1:1). Following sonication (30 mins), $1 \mathrm{~mL}$ of isopropanol was added, and the solution was spun at $10,000 \mathrm{~g}$ for $30 \mathrm{mins}$. The swab was removed, and the samples were dried using a vacuum concentrator operating at $30{ }^{\circ} \mathrm{C}$. Prior to UPLC-MS analysis, samples were reconstituted in 50 $\mu \mathrm{L}$ of HPLC-grade water, sonicated for 20 minutes and transferred to vials for analysis.

A Waters 2777C sample manager (Waters Corp., Milford, MA, USA) was used for sample handling. This was equipped with a $25 \mu \mathrm{L}$ Hamilton syringe, a $2 \mu \mathrm{L}$ loop used for fullloop injections of prepared sample, and a 3-drawer sample chamber maintained at $4{ }^{\circ} \mathrm{C}$ with a constant flow of dry nitrogen gas to prevent the build-up of condensation. The LC component was an ACQUITY UPLC (Waters Corp., Milford, MA, USA) composed of a binary solvent manager and column heater/cooler module. Metabolic profiles were acquired using reversedphase chromatography. Water and acetonitrile, each supplemented with $0.1 \%$ formic acid (mobile phases A and B, respectively), were selected for the mobile phase. A $2.1 \times 150 \mathrm{~mm}$ HSS T3 column was used at $45^{\circ} \mathrm{C}$ with a mobile phase flow rate of $0.6 \mathrm{~mL} / \mathrm{min}$. This generated a maximum pressure of $\sim 12,000 \mathrm{psi}$ in a water/acetonitrile gradient. After a $0.1 \mathrm{~min}$ isocratic separation at initial conditions (99\% A), a linear gradient elution (99\% A to $45 \%$ A in 9.9 min) 
medRxiv preprint doi: https://doi.org/10.1101/2020.06.02.20120469; this version posted June 5, 2020. The copyright holder for this preprint (which was not certified by peer review) is the author/funder, who has granted medRxiv a license to display the preprint in perpetuity. It is made available under a CC-BY-NC-ND 4.0 International license .

proceeded, followed by a quicker gradient (45\% A to $0 \% \mathrm{~A}$ in $0.7 \mathrm{~min}$ ) to final conditions. The mobile phase flow rate was simultaneously increased to $1.0 \mathrm{~mL} / \mathrm{min}$ in the latter stage to facilitate faster column washing. The MS component comprised a Xevo G2-S QToF MS (Waters Corp., Manchester, UK) coupled to the UPLC via a Zspray electrospray ionization (ESI) source. The cone gas flow was set to $150 \mathrm{~L} / \mathrm{h}$ to protect the cone from residue accumulation during operation. Both positive and negative ion modes (RPC+ and RPC-, respectively) were used. Raw spectra were converted into mzML files using MSConvert [S6] and processed with XCMS 3.6.1 in R [S7]. Peak picking and peak grouping were performed using in-house scripts in R and matrices were normalized using a median fold change approach. Log transformation, scaling and data analysis was performed in SIMCA 15.0 (Umetrics, Umea, Sweden).

Skin biopsy: The abdominal site was cleansed with (3) Chloraprep swabs (chlorhexidine 2\% and isopropyl alcohol 70\%, Becton Dickinson, Canaan, CT). Using sterile technique, local anaesthesia was obtained by infiltration of the area with $4 \mathrm{mls}$ of lidocaine $1 \%$ (Hospira, Inc., Lake Forest, IL) mixed with $1 \mathrm{ml}$ sodium bicarbonate. The skin biopsy was performed using a 6 mm punch (Miltex Instruments, York, PA). Fat tissue was carefully removed from the skin core of the biopsy using an 11-blade scalpel. The dermis and epidermis were divided into two halves, one half placed in a cryomold for OTC flash freezing (Agar Scientific, Essex, UK) and stored at $--80^{\circ} \mathrm{C}$ ), and the other half was placed in RNAlater Stabilization Solution (Thermo Fisher Scientific, Fair Lawn, N.J.), refrigerated for 24 hours, and then frozen at $-80^{\circ}$ C. The fat tissue removed from the biopsy also was divided between RNAlater and a dry Sarstedt tube that was flash frozen in liquid nitrogen and placed in -80C. The adipose tissue processed in RNAlater was refrigerated for 24 hours and then frozen at $-80 \mathrm{C}$. The biopsy site was sutured closed and a dry sterile dressing was applied. 
medRxiv preprint doi: https://doi.org/10.1101/2020.06.02.20120469; this version posted June 5, 2020. The copyright holder for this preprint (which was not certified by peer review) is the author/funder, who has granted medRxiv a license to display the preprint in perpetuity. It is made available under a CC-BY-NC-ND 4.0 International license.

\section{Supplemental References}

S1. Schubert, M. Lindgreen, S. \& Orlando, L. AdapterRemoval v2: rapid adapter trimming, identification and read merging. BMC Res Notes, 91, 88. https://doi.org/10.1186/s13104016-1900-2. (2016).

S2. $\quad$ Langmead, B. \& Salzberg, S. L. Fast gapped-read alignment with Bowtie 2. Nat Methods. 9, 357.-359. (2012).

S3. Breitwieser, F. P., Baker, D. N. \& Salzberg, S.L. KrakenUniq: confident and fast metagenomics classification using unique k-mer counts. Genome Biolog. 19, 198. https://doi.org/10.1186/s13059-018-1568-0 (2018).

S4. Holmes, I, Harris, K. \& Quince, C. Dirichlet multinomial mixtures: generative models for microbial metagenomics. PLoS One. 7, e30126. https://:doi.org/10.1371/journal.pone.0030126 (2012).

S5. Lakin S. M. et al. MEGARes: an antimicrobial resistance database for high throughput sequencing. Nucleic Acids Res. 45, D574-D580. https://doi.org/10.1093/nar/gkw1009 (2017).

S6. Chambers, M. C. et al. A cross-platform toolkit for mass spectrometry and proteomics. Nat Biotechnol. 30, 918-920. (2012).

S7. Smith, C. A., Want, E. J., Maille, G., Abagyan, R. \& Siuzdak, G. XCMS: processing mass spectrometry data for metabolite profiling using nonlinear peak alignment, matching and identification. Ana Chem. 78, 779-787. (2006). 


\section{Supplemental Tables}

Table S1

$\underline{\text { Anthropometric Measurements }}$

\begin{tabular}{lccccc}
\multicolumn{5}{c}{ Obese Cohort $\mathrm{n}=10$} & \multicolumn{5}{c}{ Non-obese Cohort $\mathrm{n}=10$} \\
\hline & Mean (+/-SD) & Range & Mean (+/-SD) & Range & $p$ \\
Age (years) & $58.8(5.8)$ & $48-69$ & $60.2(5.9)$ & $49-69$ & 0.556 \\
Weight (kg) & $109(9.9)$ & $93.4-126$ & $59.4(8)$ & $49.4-71.1$ & 0.000 \\
& & & & & \\
BMI (kg/m²) & $40.7(4.1)$ & $35.3-47.3$ & $22.4(2.7)$ & $18.7-26$ & 0.000 \\
& & & & & \\
Waist (cm) & $117(7.4)$ & $104-128$ & $80.4(10)$ & $66-98.5$ & 0.000 \\
Hip (cm) & $133(7.6)$ & $124-148$ & $96(9.3)$ & $86-115$ & 0.000 \\
Waist/hip ratio & $0.88(0.05)$ & $0.82-0.9$ & $0.84(0.06)$ & $0.77-0.94$ & 0.120
\end{tabular}

Comparison of anthropometric measurements in the 10 obese and 10 non-obese cohorts mean $+/$ - standard deviation 


\section{Supplemental Tables: Genes}

Table S1: Skin: Obese vs Non-obese $1^{\text {st }} 70$ genes

\begin{tabular}{|c|c|c|c|c|c|c|c|}
\hline$\sum_{i=0}^{D}$ & 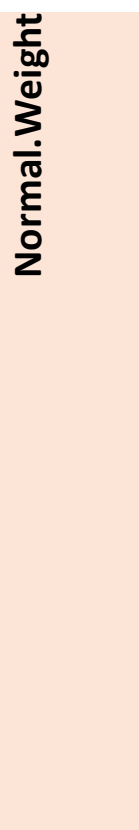 & $\begin{array}{l}\stackrel{\Xi}{ } \\
\text { О }\end{array}$ & 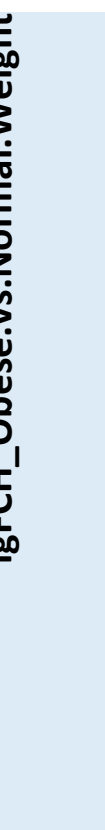 & & 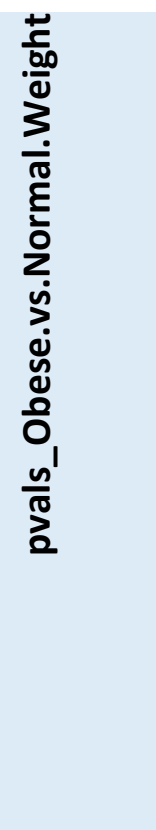 & 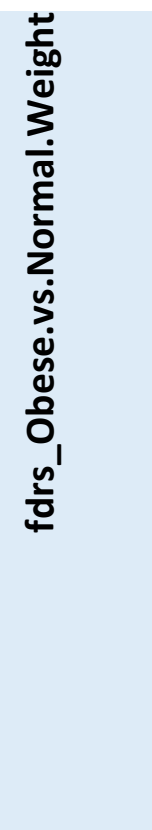 & 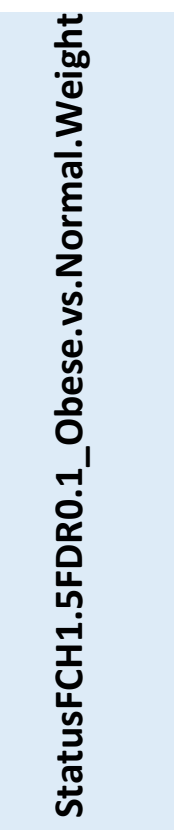 \\
\hline S100A7A & 5.99 & 7.77 & 1.78 & 3.44 & 0.00 & 0.08 & 1.00 \\
\hline DEFB4A & 7.84 & 9.48 & 1.64 & 3.11 & 0.00 & 0.07 & 1.00 \\
\hline PRG4 & 4.63 & 6.03 & 1.40 & 2.63 & 0.00 & 0.09 & 1.00 \\
\hline CORIN & 7.63 & 8.93 & 1.30 & 2.46 & 0.00 & 0.03 & 1.00 \\
\hline CORIN & 6.37 & 7.43 & 1.06 & 2.09 & 0.00 & 0.08 & 1.00 \\
\hline CNTNAP3 & 5.86 & 6.87 & 1.01 & 2.02 & 0.00 & 0.10 & 1.00 \\
\hline C1QTNF3 & 5.62 & 6.56 & 0.95 & 1.93 & 0.00 & 0.03 & 1.00 \\
\hline COL12A1 & 5.29 & 6.18 & 0.89 & 1.86 & 0.00 & 0.10 & 1.00 \\
\hline MORF4L2 & 5.84 & 6.72 & 0.88 & 1.85 & 0.00 & 0.10 & 1.00 \\
\hline FMO3 & 5.25 & 6.11 & 0.85 & 1.80 & 0.00 & 0.09 & 1.00 \\
\hline SLC16A10 & 8.81 & 9.65 & 0.84 & 1.79 & 0.00 & 0.08 & 1.00 \\
\hline CORIN & 6.78 & 7.62 & 0.84 & 1.79 & 0.00 & 0.08 & 1.00 \\
\hline LINC01091 & 7.09 & 7.90 & 0.80 & 1.75 & 0.00 & 0.06 & 1.00 \\
\hline FAM134B & 7.24 & 8.02 & 0.77 & 1.71 & 0.00 & 0.08 & 1.00 \\
\hline SPRR2C & 4.83 & 5.59 & 0.77 & 1.70 & 0.00 & 0.06 & 1.00 \\
\hline CAPZA2 & 4.02 & 4.73 & 0.70 & 1.63 & 0.00 & 0.07 & 1.00 \\
\hline WDR11 & 7.76 & 8.46 & 0.70 & 1.63 & 0.00 & 0.08 & 1.00 \\
\hline PPP2R3A & 9.38 & 10.07 & 0.69 & 1.62 & 0.00 & 0.10 & 1.00 \\
\hline TRAK1 & 8.54 & 9.23 & 0.70 & 1.62 & 0.00 & 0.06 & 1.00 \\
\hline PTPRK & 6.03 & 6.70 & 0.68 & 1.60 & 0.00 & 0.07 & 1.00 \\
\hline EIF3M & 7.15 & 7.82 & 0.67 & 1.59 & 0.00 & 0.09 & 1.00 \\
\hline
\end{tabular}


medRxiv preprint doi: https://doi.org/10.1101/2020.06.02.20120469; this version posted June 5, 2020. The copyright holder for this preprint

(which was not certified by peer review) is the author/funder, who has granted medRxiv a license to display the preprint in perpetuity.

It is made available under a CC-BY-NC-ND 4.0 International license .

\begin{tabular}{|c|c|c|c|c|c|c|c|}
\hline Table $S 1$ cont'd & & & & & & & \\
\hline RHOA & 5.84 & 6.49 & 0.65 & 1.57 & 0.00 & 0.08 & 1.00 \\
\hline TRAK1 & 5.69 & 6.34 & 0.65 & 1.56 & 0.00 & 0.03 & 1.00 \\
\hline P2RY1 & 6.11 & 6.74 & 0.63 & 1.55 & 0.00 & 0.10 & 1.00 \\
\hline ASPM & 5.86 & 6.49 & 0.63 & 1.55 & 0.00 & 0.05 & 1.00 \\
\hline RAB27B & 6.88 & 7.50 & 0.63 & 1.54 & 0.00 & 0.02 & 1.00 \\
\hline NRIP1 & 6.70 & 7.32 & 0.61 & 1.53 & 0.00 & 0.08 & 1.00 \\
\hline WASL & 8.31 & 8.92 & 0.61 & 1.53 & 0.00 & 0.04 & 1.00 \\
\hline TRPC6 & 6.81 & 7.42 & 0.61 & 1.53 & 0.00 & 0.02 & 1.00 \\
\hline ATP10B & 7.92 & 8.53 & 0.61 & 1.53 & 0.00 & 0.10 & 1.00 \\
\hline HIST1H2BC & 6.34 & 6.94 & 0.60 & 1.52 & 0.00 & 0.02 & 1.00 \\
\hline HECTD4 & 6.34 & 6.93 & 0.59 & 1.51 & 0.00 & 0.09 & 1.00 \\
\hline LOC284930 & 7.64 & 8.23 & 0.59 & 1.51 & 0.00 & 0.03 & 1.00 \\
\hline BMP2 & 7.56 & 8.15 & 0.59 & 1.51 & 0.00 & 0.10 & 1.00 \\
\hline EZR & 9.10 & 9.69 & 0.59 & 1.51 & 0.00 & 0.06 & 1.00 \\
\hline EML6 & 6.07 & 6.67 & 0.60 & 1.51 & 0.00 & 0.10 & 1.00 \\
\hline ARHGAP44 & 8.53 & 7.94 & -0.59 & -1.50 & 0.00 & 0.08 & -1.00 \\
\hline LINC00950 & 6.20 & 5.61 & -0.59 & -1.50 & 0.00 & 0.03 & -1.00 \\
\hline MYO5C & 10.53 & 9.94 & -0.59 & -1.50 & 0.00 & 0.06 & -1.00 \\
\hline KLHDC9 & 6.25 & 5.66 & -0.59 & -1.50 & 0.00 & 0.05 & -1.00 \\
\hline LOC441242 & 5.43 & 4.84 & -0.59 & -1.50 & 0.00 & 0.06 & -1.00 \\
\hline RASL10A & 5.72 & 5.13 & -0.59 & -1.51 & 0.00 & 0.09 & -1.00 \\
\hline GGTLC1 & 7.82 & 7.23 & -0.59 & -1.51 & 0.00 & 0.07 & -1.00 \\
\hline SPDEF & 7.39 & 6.79 & -0.60 & -1.51 & 0.00 & 0.08 & -1.00 \\
\hline MRAS & 9.78 & 9.19 & -0.59 & -1.51 & 0.00 & 0.09 & -1.00 \\
\hline FAM27E3 & 6.73 & 6.13 & -0.60 & -1.51 & 0.00 & 0.10 & -1.00 \\
\hline ENPP5 & 8.22 & 7.62 & -0.60 & -1.51 & 0.00 & 0.07 & -1.00 \\
\hline SCAND2P & 8.53 & 7.93 & -0.59 & -1.51 & 0.00 & 0.05 & -1.00 \\
\hline DOK6 & 5.94 & 5.35 & -0.60 & -1.51 & 0.00 & 0.10 & -1.00 \\
\hline SOCS2 & 6.45 & 5.86 & -0.59 & -1.51 & 0.00 & 0.05 & -1.00 \\
\hline SGSM2 & 10.97 & 10.37 & -0.60 & -1.51 & 0.00 & 0.07 & -1.00 \\
\hline BRE-AS1 & 4.59 & 3.99 & -0.61 & -1.52 & 0.00 & 0.09 & -1.00 \\
\hline REEP1 & 8.44 & 7.84 & -0.60 & -1.52 & 0.00 & 0.05 & -1.00 \\
\hline CYP2C9 & 6.59 & 5.99 & -0.61 & -1.52 & 0.00 & 0.06 & -1.00 \\
\hline ZBED8 & 7.70 & 7.10 & -0.60 & -1.52 & 0.00 & 0.10 & -1.00 \\
\hline CPAMD8 & 6.00 & 5.39 & -0.61 & -1.52 & 0.00 & 0.04 & -1.00 \\
\hline DNAH1 & 8.96 & 8.35 & -0.61 & -1.52 & 0.00 & 0.10 & -1.00 \\
\hline
\end{tabular}




\section{Table S2}

Skin: Obese vs Non-obese last 70 genes

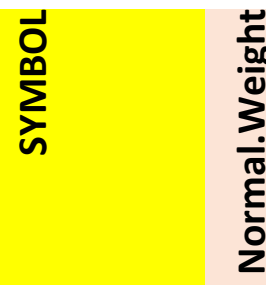

$\searrow$
음
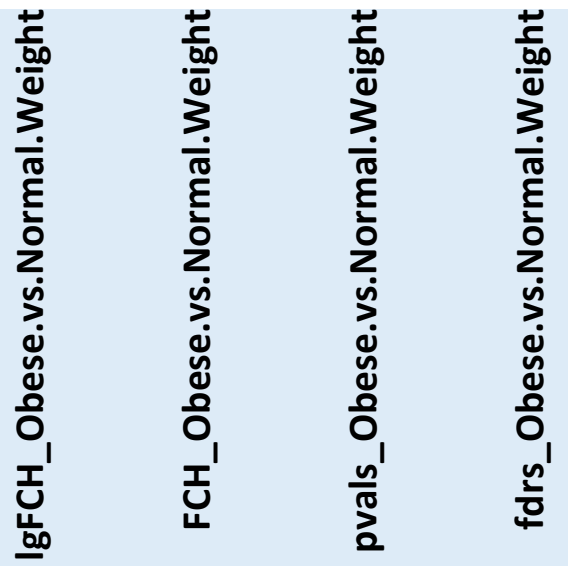

\begin{tabular}{|c|c|c|c|c|c|c|c|}
\hline SHANK2 & 7.03 & 5.80 & -1.23 & -2.35 & 0.00 & 0.04 & -1.00 \\
\hline TOX3 & 5.95 & 4.69 & -1.26 & -2.39 & 0.00 & 0.04 & -1.00 \\
\hline PPP1R1B & 9.26 & 7.99 & -1.26 & -2.40 & 0.00 & 0.03 & -1.00 \\
\hline STAC2 & 8.49 & 7.23 & -1.26 & -2.40 & 0.00 & 0.05 & -1.00 \\
\hline MEGF10 & 7.01 & 5.73 & -1.28 & -2.42 & 0.00 & 0.08 & -1.00 \\
\hline SH3GL2 & 4.79 & 3.51 & -1.29 & -2.44 & 0.00 & 0.06 & -1.00 \\
\hline EPHA7 & 7.42 & 6.14 & -1.29 & -2.44 & 0.00 & 0.07 & -1.00 \\
\hline FUT9 & 4.78 & 3.47 & -1.31 & -2.47 & 0.00 & 0.05 & -1.00 \\
\hline CLCNKB & 8.28 & 6.96 & -1.32 & -2.49 & 0.00 & 0.05 & -1.00 \\
\hline SFRP1 & 11.51 & 10.19 & -1.32 & -2.50 & 0.00 & 0.07 & -1.00 \\
\hline MMP7 & 9.51 & 8.19 & -1.32 & -2.50 & 0.00 & 0.05 & -1.00 \\
\hline KCNK5 & 9.64 & 8.31 & -1.33 & -2.51 & 0.00 & 0.08 & -1.00 \\
\hline ATP6V1B1 & 7.94 & 6.60 & -1.34 & -2.53 & 0.00 & 0.04 & -1.00 \\
\hline B3GALT5 & 8.78 & 7.44 & -1.34 & -2.54 & 0.00 & 0.07 & -1.00 \\
\hline KRT18 & 10.06 & 8.71 & -1.35 & -2.55 & 0.00 & 0.02 & -1.00 \\
\hline CEACAM6 & 8.96 & 7.60 & -1.36 & -2.56 & 0.00 & 0.05 & -1.00 \\
\hline F5 & 6.91 & 5.54 & -1.36 & -2.57 & 0.00 & 0.07 & -1.00 \\
\hline CEACAM5 & 8.21 & 6.84 & -1.37 & -2.58 & 0.00 & 0.09 & -1.00 \\
\hline SLC34A2 & 5.87 & 4.50 & -1.37 & -2.59 & 0.00 & 0.08 & -1.00 \\
\hline ROPN1 & 5.68 & 4.31 & -1.37 & -2.59 & 0.00 & 0.02 & -1.00 \\
\hline GABRP & 9.40 & 8.01 & -1.39 & -2.63 & 0.00 & 0.10 & -1.00 \\
\hline TTC6 & 5.49 & 4.06 & -1.42 & -2.68 & 0.00 & 0.10 & -1.00 \\
\hline
\end{tabular}


medRxiv preprint doi: https://doi.org/10.1101/2020.06.02.20120469; this version posted June 5, 2020. The copyright holder for this preprint

(which was not certified by peer review) is the author/funder, who has granted medRxiv a license to display the preprint in perpetuity.

It is made available under a CC-BY-NC-ND 4.0 International license .

\section{Table S2 cont'd}

\begin{tabular}{|c|c|c|c|c|c|c|c|}
\hline SFRP1 & 8.81 & 7.35 & -1.46 & -2.75 & 0.00 & 0.03 & -1.00 \\
\hline UGT8 & 7.07 & 5.59 & -1.48 & -2.79 & 0.00 & 0.06 & -1.00 \\
\hline PRR4 & 9.65 & 8.16 & -1.49 & -2.81 & 0.00 & 0.08 & -1.00 \\
\hline CFTR & 8.08 & 6.58 & -1.50 & -2.82 & 0.00 & 0.07 & -1.00 \\
\hline SPX & 4.39 & 2.88 & -1.51 & -2.84 & 0.00 & 0.06 & -1.00 \\
\hline VTCN1 & 6.86 & 5.35 & -1.52 & -2.86 & 0.00 & 0.04 & -1.00 \\
\hline GRIA2 & 5.80 & 4.27 & -1.53 & -2.88 & 0.00 & 0.10 & -1.00 \\
\hline RHPN2 & 9.59 & 8.05 & -1.54 & -2.91 & 0.00 & 0.09 & -1.00 \\
\hline OBP2B & 7.33 & 5.79 & -1.54 & -2.91 & 0.00 & 0.03 & -1.00 \\
\hline LMF1 & 8.43 & 6.88 & -1.55 & -2.93 & 0.00 & 0.04 & -1.00 \\
\hline GLYATL2 & 7.26 & 5.71 & -1.55 & -2.94 & 0.00 & 0.05 & -1.00 \\
\hline ATP6V0A4 & 10.27 & 8.70 & -1.58 & -2.98 & 0.00 & 0.08 & -1.00 \\
\hline SHANK2 & 7.41 & 5.82 & -1.59 & -3.01 & 0.00 & 0.04 & -1.00 \\
\hline LMF1 & 7.55 & 5.95 & -1.60 & -3.03 & 0.00 & 0.04 & -1.00 \\
\hline CEACAM1 & 7.42 & 5.81 & -1.60 & -3.04 & 0.00 & 0.06 & -1.00 \\
\hline PADI2 & 10.32 & 8.71 & -1.61 & -3.05 & 0.00 & 0.04 & -1.00 \\
\hline ELF5 & 10.17 & 8.56 & -1.61 & -3.06 & 0.00 & 0.07 & -1.00 \\
\hline MB & 7.79 & 6.16 & -1.62 & -3.08 & 0.00 & 0.03 & -1.00 \\
\hline PIGR & 7.70 & 6.08 & -1.62 & -3.08 & 0.00 & 0.09 & -1.00 \\
\hline ADCY8 & 7.31 & 5.68 & -1.63 & -3.09 & 0.00 & 0.02 & -1.00 \\
\hline IREB2 & 5.97 & 4.31 & -1.65 & -3.14 & 0.00 & 0.09 & -1.00 \\
\hline CHRM3 & 6.77 & 5.12 & -1.65 & -3.14 & 0.00 & 0.02 & -1.00 \\
\hline MYBPC1 & 8.26 & 6.57 & -1.69 & -3.23 & 0.00 & 0.07 & -1.00 \\
\hline OBP2B & 6.92 & 5.22 & -1.69 & -3.23 & 0.00 & 0.05 & -1.00 \\
\hline TMPRSS2 & 8.28 & 6.56 & -1.72 & -3.29 & 0.00 & 0.02 & -1.00 \\
\hline ROPN1 & 8.63 & 6.90 & -1.73 & -3.32 & 0.00 & 0.06 & -1.00 \\
\hline ROPN1 & 8.43 & 6.69 & -1.74 & -3.34 & 0.00 & 0.05 & -1.00 \\
\hline KRT7 & 6.91 & 5.15 & -1.76 & -3.38 & 0.00 & 0.03 & -1.00 \\
\hline ROPN1 & 8.15 & 6.39 & -1.76 & -3.39 & 0.00 & 0.06 & -1.00 \\
\hline SLC26A7 & 7.04 & 5.21 & -1.83 & -3.57 & 0.00 & 0.07 & -1.00 \\
\hline GRIA2 & 6.47 & 4.63 & -1.85 & -3.59 & 0.00 & 0.07 & -1.00 \\
\hline DNER & 10.02 & 8.17 & -1.85 & -3.61 & 0.00 & 0.08 & -1.00 \\
\hline GRB14 & 9.20 & 7.34 & -1.86 & -3.63 & 0.00 & 0.06 & -1.00 \\
\hline FOXI1 & 6.78 & 4.91 & -1.87 & -3.65 & 0.00 & 0.03 & -1.00 \\
\hline KRT7 & 8.87 & 7.01 & -1.87 & -3.65 & 0.00 & 0.03 & -1.00 \\
\hline KRT19 & 9.64 & 7.75 & -1.89 & -3.71 & 0.00 & 0.05 & -1.00 \\
\hline TMEM213 & 7.92 & 6.03 & -1.90 & -3.72 & 0.00 & 0.10 & -1.00 \\
\hline PIGR & 8.43 & 6.52 & -1.90 & -3.74 & 0.00 & 0.08 & -1.00 \\
\hline KIAA1324 & 9.14 & 7.21 & -1.93 & -3.81 & 0.00 & 0.02 & -1.00 \\
\hline CHRM3 & 7.90 & 5.95 & -1.95 & -3.86 & 0.00 & 0.03 & -1.00 \\
\hline KIAA1324 & 8.71 & 6.75 & -1.95 & -3.87 & 0.00 & 0.09 & -1.00 \\
\hline
\end{tabular}


medRxiv preprint doi: https://doi.org/10.1101/2020.06.02.20120469; this version posted June 5, 2020. The copyright holder for this preprint (which was not certified by peer review) is the author/funder, who has granted medRxiv a license to display the preprint in perpetuity.

\title{
Table S2 cont'd
}

\begin{abstract}
It is made available under a CC-BY-NC-ND 4.0 International license.
\end{abstract}

\begin{tabular}{lr|l|lllll} 
MFI2 & 8.11 & 6.00 & -2.11 & -4.33 & 0.00 & 0.03 & -1.00 \\
\hline NELL1 & 7.11 & 4.91 & -2.20 & -4.61 & 0.00 & 0.03 & -1.00 \\
\hline CLDN10 & 9.84 & 7.58 & -2.26 & -4.81 & 0.00 & 0.07 & -1.00 \\
KRT19 & 10.66 & 8.35 & -2.31 & -4.96 & 0.00 & 0.03 & -1.00 \\
SLC14A1 & 8.95 & 6.59 & -2.36 & -5.15 & 0.00 & 0.05 & -1.00 \\
PROM1 & 9.21 & 6.72 & -2.50 & -5.65 & 0.00 & 0.04 & -1.00 \\
AQP5 & 9.66 & 7.12 & -2.54 & -5.81 & 0.00 & 0.07 & -1.00 \\
CRISP3 & 9.12 & 6.54 & -2.57 & -5.95 & 0.00 & 0.06 & -1.00
\end{tabular}




\section{Table S3}

Fat: Obese vs Non-obese $1^{\text {st }} 70$ genes

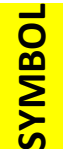

SPP1

SPP1

EGFL6

UNC13C

MMP9

SERPINB3

IL1RN

SPRR1A

PLA2G7

SERPINB3

S100A7A

THBS1

SPRR1B

CHI3L1

SERPINB4

DEFB4A

KRTDAP

SPRR3

LCE3D

SPRR2G

CHI3L1

UNC13C
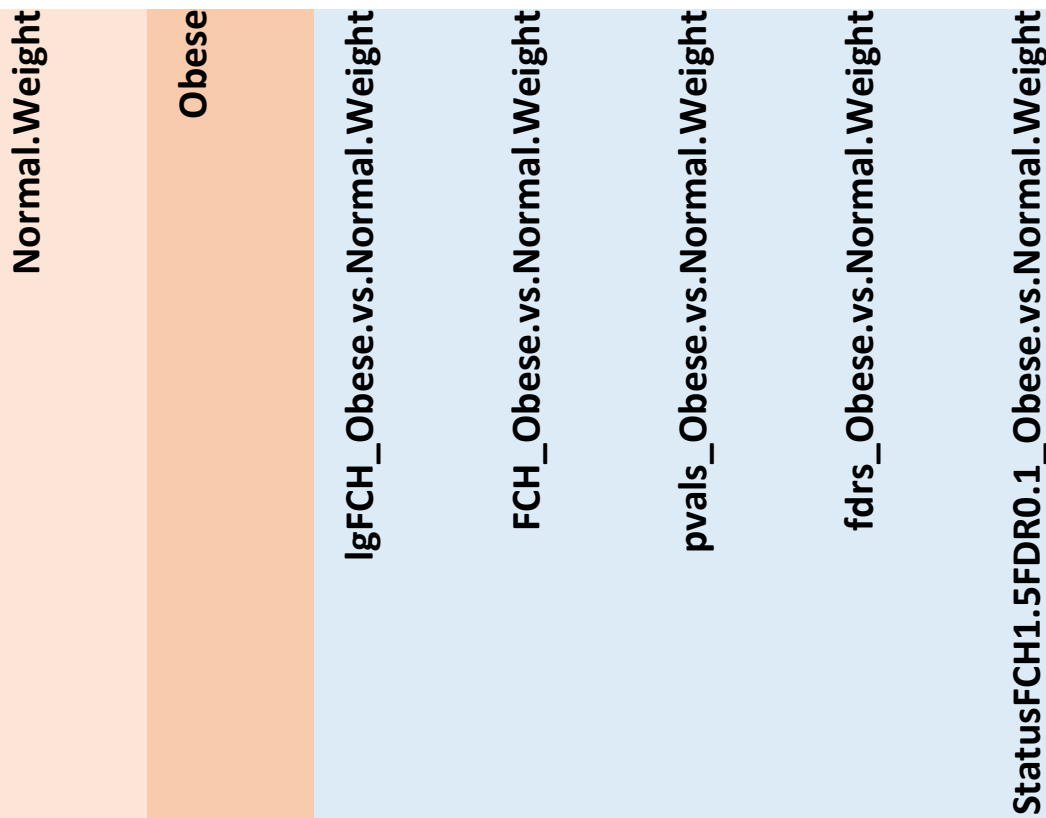

\begin{tabular}{|c|c|c|c|c|c|c|}
\hline 5.04 & 8.57 & 3.53 & 11.52 & 0.00 & 0.00 & 1.00 \\
\hline 6.89 & 10.05 & 3.16 & 8.96 & 0.00 & 0.00 & 1.00 \\
\hline 8.32 & 11.40 & 3.09 & 8.51 & 0.00 & 0.01 & 1.00 \\
\hline 4.14 & 7.05 & 2.91 & 7.54 & 0.00 & 0.00 & 1.00 \\
\hline 5.61 & 8.43 & 2.82 & 7.07 & 0.00 & 0.00 & 1.00 \\
\hline 5.05 & 7.86 & 2.81 & 7.00 & 0.00 & 0.00 & 1.00 \\
\hline 6.47 & 9.25 & 2.78 & 6.86 & 0.00 & 0.00 & 1.00 \\
\hline 3.60 & 6.31 & 2.71 & 6.56 & 0.00 & 0.00 & 1.00 \\
\hline 5.49 & 8.14 & 2.66 & 6.30 & 0.00 & 0.00 & 1.00 \\
\hline 3.99 & 6.64 & 2.64 & 6.25 & 0.00 & 0.00 & 1.00 \\
\hline 5.05 & 7.64 & 2.59 & 6.01 & 0.00 & 0.00 & 1.00 \\
\hline 6.60 & 9.14 & 2.54 & 5.83 & 0.00 & 0.00 & 1.00 \\
\hline 6.24 & 8.78 & 2.54 & 5.82 & 0.00 & 0.00 & 1.00 \\
\hline 6.45 & 8.96 & 2.51 & 5.69 & 0.00 & 0.00 & 1.00 \\
\hline 4.85 & 7.34 & 2.50 & 5.64 & 0.00 & 0.00 & 1.00 \\
\hline 7.36 & 9.71 & 2.35 & 5.09 & 0.00 & 0.00 & 1.00 \\
\hline 6.57 & 8.86 & 2.29 & 4.88 & 0.00 & 0.00 & 1.00 \\
\hline 6.34 & 8.62 & 2.28 & 4.86 & 0.00 & 0.00 & 1.00 \\
\hline 4.89 & 7.15 & 2.25 & 4.77 & 0.00 & 0.01 & 1.00 \\
\hline 6.35 & 8.56 & 2.21 & 4.63 & 0.00 & 0.00 & 1.00 \\
\hline 6.11 & 8.29 & 2.18 & 4.52 & 0.00 & 0.00 & 1.00 \\
\hline 3.12 & 5.29 & 2.17 & 4.51 & 0.00 & 0.00 & 1.00 \\
\hline
\end{tabular}


medRxiv preprint doi: https://doi.org/10.1101/2020.06.02.20120469; this version posted June 5, 2020. The copyright holder for this preprint

\begin{tabular}{|c|c|c|c|c|c|c|c|}
\hline Table S3 cont'd & & & & & & & \\
\hline COMP & 5.29 & 7.46 & 2.17 & 4.49 & 0.00 & 0.02 & 1.00 \\
\hline LAMP3 & 4.26 & 6.41 & 2.15 & 4.45 & 0.00 & 0.00 & 1.00 \\
\hline PI3 & 6.50 & 8.65 & 2.15 & 4.42 & 0.00 & 0.00 & 1.00 \\
\hline ABCC3 & 5.99 & 8.11 & 2.12 & 4.34 & 0.00 & 0.00 & 1.00 \\
\hline LINC00968 & 7.00 & 9.12 & 2.12 & 4.34 & 0.00 & 0.00 & 1.00 \\
\hline ACTC1 & 5.93 & 8.04 & 2.11 & 4.33 & 0.02 & 0.10 & 1.00 \\
\hline SCIN & 5.89 & 7.99 & 2.10 & 4.29 & 0.00 & 0.02 & 1.00 \\
\hline PI3 & 6.89 & 8.99 & 2.10 & 4.29 & 0.00 & 0.00 & 1.00 \\
\hline TNC & 4.83 & 6.91 & 2.07 & 4.21 & 0.00 & 0.02 & 1.00 \\
\hline COL11A1 & 5.54 & 7.62 & 2.08 & 4.21 & 0.00 & 0.00 & 1.00 \\
\hline DCSTAMP & 3.62 & 5.69 & 2.06 & 4.18 & 0.00 & 0.00 & 1.00 \\
\hline S100A7 & 9.20 & 11.24 & 2.05 & 4.13 & 0.00 & 0.00 & 1.00 \\
\hline TNC & 4.71 & 6.74 & 2.03 & 4.08 & 0.00 & 0.01 & 1.00 \\
\hline FCGR1B & 5.15 & 7.17 & 2.02 & 4.07 & 0.00 & 0.00 & 1.00 \\
\hline IGLV1-44 & 3.77 & 5.78 & 2.01 & 4.04 & 0.00 & 0.00 & 1.00 \\
\hline SPRR2D & 6.41 & 8.38 & 1.97 & 3.92 & 0.00 & 0.01 & 1.00 \\
\hline FCGBP & 6.32 & 8.29 & 1.96 & 3.90 & 0.00 & 0.00 & 1.00 \\
\hline CCL22 & 5.19 & 7.15 & 1.96 & 3.88 & 0.00 & 0.00 & 1.00 \\
\hline NPR3 & 7.36 & 9.29 & 1.94 & 3.83 & 0.00 & 0.02 & 1.00 \\
\hline TNC & 8.26 & 10.18 & 1.92 & 3.79 & 0.00 & 0.02 & 1.00 \\
\hline UBE2QL1 & 5.06 & 6.98 & 1.92 & 3.79 & 0.00 & 0.00 & 1.00 \\
\hline CXCL8 & 4.88 & 6.75 & 1.87 & 3.66 & 0.00 & 0.00 & 1.00 \\
\hline IGLC1 & 5.11 & 6.97 & 1.86 & 3.62 & 0.00 & 0.01 & 1.00 \\
\hline POPDC3 & 3.51 & 5.37 & 1.85 & 3.62 & 0.00 & 0.01 & 1.00 \\
\hline PPP2R2C & 5.59 & 7.44 & 1.85 & 3.61 & 0.01 & 0.04 & 1.00 \\
\hline IGH & 6.90 & 8.74 & 1.84 & 3.58 & 0.00 & 0.01 & 1.00 \\
\hline SELE & 4.55 & 6.38 & 1.83 & 3.57 & 0.00 & 0.00 & 1.00 \\
\hline CLEC7A & 5.22 & 7.05 & 1.83 & 3.55 & 0.00 & 0.00 & 1.00 \\
\hline UCHL1 & 9.50 & 11.33 & 1.83 & 3.55 & 0.00 & 0.00 & 1.00 \\
\hline \multirow[t]{2}{*}{ LOC101929398 } & 6.14 & 7.96 & 1.82 & 3.53 & 0.00 & 0.01 & 1.00 \\
\hline & 5.47 & 6.30 & 0.83 & 1.78 & 0.01 & 0.06 & 1.00 \\
\hline TREM2 & 4.77 & 6.59 & 1.82 & 3.52 & 0.00 & 0.00 & 1.00 \\
\hline THBS1 & 8.02 & 9.84 & 1.81 & 3.51 & 0.00 & 0.03 & 1.00 \\
\hline FCGR1A & 5.88 & 7.66 & 1.78 & 3.44 & 0.00 & 0.00 & 1.00 \\
\hline P2RX1 & 6.94 & 8.72 & 1.77 & 3.42 & 0.01 & 0.07 & 1.00 \\
\hline RGS1 & 3.53 & 5.30 & 1.77 & 3.42 & 0.00 & 0.00 & 1.00 \\
\hline CCL3 & 5.45 & 7.21 & 1.76 & 3.40 & 0.00 & 0.00 & 1.00 \\
\hline SERPINB13 & 3.15 & 4.92 & 1.77 & 3.40 & 0.00 & 0.02 & 1.00 \\
\hline FCGR1A & 3.70 & 5.46 & 1.76 & 3.39 & 0.00 & 0.00 & 1.00 \\
\hline SCIN & 5.05 & 6.80 & 1.75 & 3.36 & 0.00 & 0.03 & 1.00 \\
\hline SBSN & 4.90 & 6.65 & 1.74 & 3.35 & 0.00 & 0.01 & 1.00 \\
\hline
\end{tabular}


medRxiv preprint doi: https://doi.org/10.1101/2020.06.02.20120469; this version posted June 5, 2020. The copyright holder for this preprint (which was not certified by peer review) is the author/funder, who has granted medRxiv a license to display the preprint in perpetuity.

It is made available under a CC-BY-NC-ND 4.0 International license .

\section{Table S3 cont'd}

\begin{tabular}{|c|c|c|c|c|c|c|c|}
\hline SPRR1A & 6.31 & 8.03 & 1.72 & 3.30 & 0.00 & 0.00 & 1.00 \\
\hline DIO2 & 4.88 & 6.60 & 1.72 & 3.30 & 0.01 & 0.05 & 1.00 \\
\hline CEP55 & 4.67 & 6.37 & 1.70 & 3.25 & 0.00 & 0.00 & 1.00 \\
\hline ADAMDEC1 & 2.82 & 4.52 & 1.69 & 3.24 & 0.00 & 0.00 & 1.00 \\
\hline KRT6A & 6.14 & 7.84 & 1.70 & 3.24 & 0.01 & 0.06 & 1.00 \\
\hline ARG1 & 3.55 & 5.23 & 1.68 & 3.21 & 0.00 & 0.02 & 1.00 \\
\hline TRAT1 & 5.04 & 6.71 & 1.67 & 3.18 & 0.00 & 0.00 & 1.00 \\
\hline RRM2 & 4.34 & 6.00 & 1.66 & 3.15 & 0.00 & 0.00 & 1.00 \\
\hline ACTA1 & 4.24 & 5.90 & 1.65 & 3.14 & 0.01 & 0.07 & 1.00 \\
\hline
\end{tabular}




\section{Table S4}

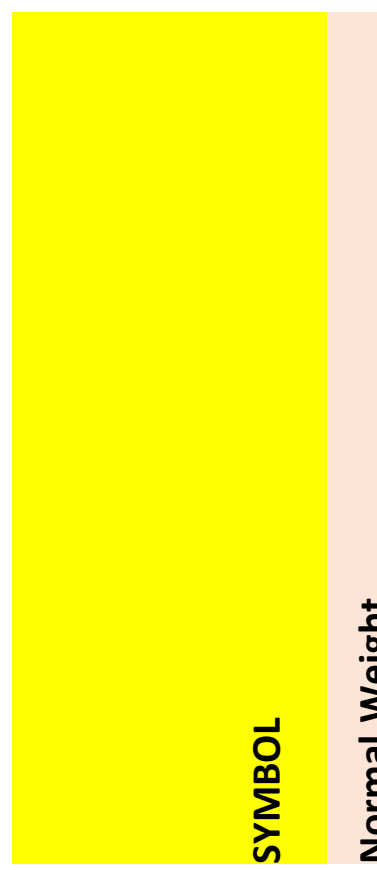

GYS2

TSHR

CHODL

CPNE4

CYP4F29P

CIDEA

SYT17

RASL10B

WDR86

NAALAD2

CPNE4

GLUL

RGS3

CAPN6

GSDMB

CECR2
Fat: Obese vs Non-obese last 70 genes
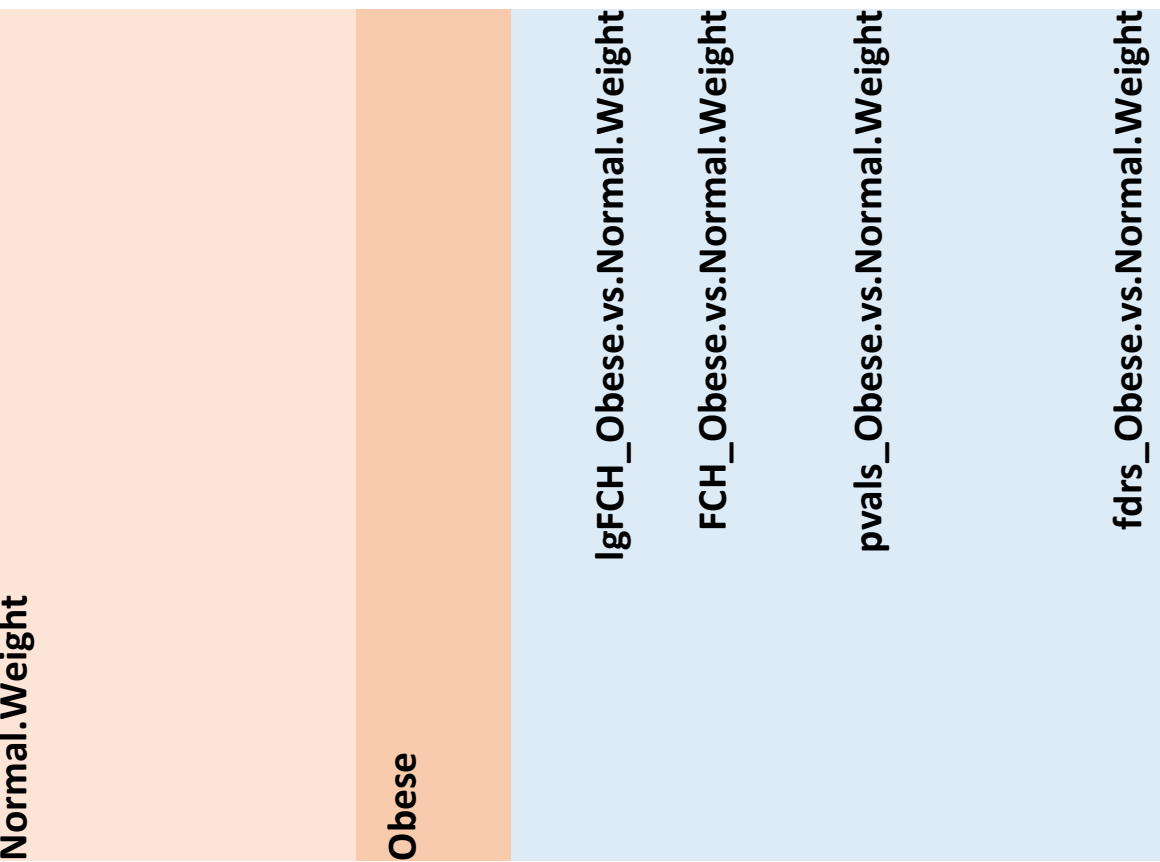

\subsection{6 \\ 5.955878}

6.581453

$-1.48$

4.452574

$-1.5$

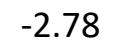

-2.78
-2.83

0.00719

$-1.5$

$-2.83$

0.0129

0.0527

0.0748

5.449809

3.948163

0.7

1.63

4.01E-05

0.00286

3.709156

4.413575

$-1.5$

$-2.83$

0.000357

0.0091

0.00889

7.56177

6.055927

$-1.51$

$-2.84$

0.000344

0.00897

$10.59601 \quad 9.087702$

$-1.51$

$-2.84$

$7.402136 \quad 5.889865$

$-1.51$

$-2.85$

7.02E-05

0.00447

6.27391

$-0.7$

$-1.63$

8.51E-06

0.00373

$-2.87$

$5.52 \mathrm{E}-05$

0.00129

0.00334

6.4348464 .914091

$-1.52$

1.98

0.00378

0.0357

3.92753

1.58

0.0111

0.0684

$-2.91 \quad 9.19 \mathrm{E}-05$

0.00432

$-2.93$

$1.95 \mathrm{E}-08$

0.0

7.778574

8.25292

$-2.42$

0.00137

$-2.96$

0.000804

$-2.97 \quad 4.56 \mathrm{E}-07$

$-2.97$

4.61E-07

10.13124

9.325681

$-1.57$

7.416375

5.839098

$-1.58$

$-2.98$

2.47E-07

\section{$\begin{array}{ll}1.6 & 0.00278\end{array}$}

-3 5.95E-08

$-1.58$

9.557125

7.974478

$-1.62$

$-3.07$

0.00141

$\begin{array}{ll}1.77 & 0.000891\end{array}$

$1.5 \quad 2.38 \mathrm{E}-05$

$\begin{array}{ll}-2.1 & 0.00353\end{array}$

$\begin{array}{lll}5.980785 & 6.804565 & 0.82\end{array}$

0.59

4.4053413 .332135

$-1.07$ 
medRxiv preprint doi: https://doi.org/10.1101/2020.06.02.20120469; this version posted June 5, 2020. The copyright holder for this preprint (which was not certified by peer review) is the author/funder, who has granted medRxiv a license to display the preprint in perpetuity. It is made available under a CC-BY-NC-ND 4.0 International license.

\section{Table S 4 cont'd}

\begin{tabular}{|c|c|c|c|c|c|c|c|}
\hline \multirow[t]{2}{*}{ CETP } & 8.405207 & 6.779649 & -1.63 & -3.09 & 0.000457 & 0.0105 & -1 \\
\hline & 7.019169 & 6.390175 & -0.63 & -1.55 & 0.019 & 0.0948 & -1 \\
\hline \multirow[t]{2}{*}{ AZGP1 } & 11.80998 & 10.16363 & -1.65 & -3.13 & $1.03 \mathrm{E}-05$ & 0.00142 & -1 \\
\hline & 6.50 & 5.76 & -0.75 & -1.68 & 0.00 & 0.00 & -1.00 \\
\hline STOX1 & 9.73 & 8.08 & -1.65 & -3.13 & 0.00 & 0.00 & -1.00 \\
\hline ALPK3 & 9.09 & 7.43 & -1.65 & -3.14 & 0.00 & 0.00 & -1.00 \\
\hline APOB & 10.27 & 8.61 & -1.66 & -3.17 & 0.00 & 0.00 & -1.00 \\
\hline \multirow[t]{2}{*}{ ALPK3 } & 9.18 & 7.51 & -1.67 & -3.18 & 0.00 & 0.00 & -1.00 \\
\hline & 7.61 & 8.30 & 0.69 & 1.61 & 0.00 & 0.01 & 1.00 \\
\hline GLUL & 9.84 & 8.16 & -1.68 & -3.20 & 0.00 & 0.00 & -1.00 \\
\hline OK/SW-CL.36 & 4.99 & 3.28 & -1.71 & -3.27 & 0.00 & 0.01 & -1.00 \\
\hline DMRT2 & 8.88 & 7.16 & -1.72 & -3.28 & 0.00 & 0.01 & -1.00 \\
\hline \multirow[t]{3}{*}{ LOC105376379 } & 6.04 & 4.32 & -1.71 & -3.28 & 0.00 & 0.01 & -1.00 \\
\hline & 3.63 & 4.34 & 0.71 & 1.64 & 0.01 & 0.05 & 1.00 \\
\hline & 4.58 & 5.61 & 1.03 & 2.04 & 0.00 & 0.01 & 1.00 \\
\hline TOX3 & 5.68 & 3.95 & -1.73 & -3.32 & 0.02 & 0.08 & -1.00 \\
\hline \multirow[t]{2}{*}{ EYA1 } & 6.63 & 4.89 & -1.74 & -3.35 & 0.00 & 0.00 & -1.00 \\
\hline & 6.54 & 5.71 & -0.83 & -1.78 & 0.00 & 0.01 & -1.00 \\
\hline TOX3 & 5.84 & 4.03 & -1.80 & -3.49 & 0.01 & 0.07 & -1.00 \\
\hline \multirow[t]{3}{*}{ FCN2 } & 6.61 & 4.76 & -1.86 & -3.62 & 0.00 & 0.01 & -1.00 \\
\hline & 4.94 & 5.54 & 0.60 & 1.51 & 0.00 & 0.00 & 1.00 \\
\hline & 7.65 & 8.62 & 0.97 & 1.96 & 0.00 & 0.01 & 1.00 \\
\hline COL6A6 & 6.36 & 4.51 & -1.86 & -3.63 & 0.00 & 0.00 & -1.00 \\
\hline AZGP1 & 11.30 & 9.42 & -1.88 & -3.67 & 0.00 & 0.00 & -1.00 \\
\hline \multirow[t]{2}{*}{ LOC90768 } & 7.53 & 5.65 & -1.88 & -3.68 & 0.00 & 0.00 & -1.00 \\
\hline & 6.05 & 6.91 & 0.87 & 1.82 & 0.00 & 0.03 & 1.00 \\
\hline ALDH1L1-AS2 & 7.54 & 5.66 & -1.89 & -3.70 & 0.00 & 0.00 & -1.00 \\
\hline LDHD & 8.00 & 6.11 & -1.89 & -3.71 & 0.00 & 0.00 & -1.00 \\
\hline GLUL & 8.81 & 6.92 & -1.89 & -3.72 & 0.00 & 0.00 & -1.00 \\
\hline SPX & 11.14 & 9.17 & -1.97 & -3.92 & 0.00 & 0.00 & -1.00 \\
\hline GSDMB & 8.20 & 6.20 & -2.00 & -4.01 & 0.00 & 0.00 & -1.00 \\
\hline GPAT3 & 10.43 & 8.40 & -2.03 & -4.09 & 0.00 & 0.00 & -1.00 \\
\hline PKP2 & 7.81 & 5.76 & -2.05 & -4.14 & 0.00 & 0.01 & -1.00 \\
\hline RASSF6 & 6.20 & 4.08 & -2.12 & -4.34 & 0.00 & 0.02 & -1.00 \\
\hline NWD2 & 7.31 & 5.04 & -2.27 & -4.81 & 0.00 & 0.00 & -1.00 \\
\hline C6 & 10.04 & 7.74 & -2.30 & -4.93 & 0.00 & 0.00 & -1.00 \\
\hline FAM95A & 6.42 & 4.09 & -2.33 & -5.02 & 0.00 & 0.00 & -1.00 \\
\hline COL6A6 & 9.60 & 7.25 & -2.35 & -5.09 & 0.00 & 0.00 & -1.00 \\
\hline STOX1 & 8.67 & 6.32 & -2.35 & -5.10 & 0.00 & 0.00 & -1.00 \\
\hline CA3 & 10.47 & 8.02 & -2.45 & -5.46 & 0.00 & 0.00 & -1.00 \\
\hline RORB & 6.57 & 3.47 & -3.11 & -8.61 & 0.00 & 0.00 & -1.00 \\
\hline
\end{tabular}


medRxiv preprint doi: https://doi.org/10.1101/2020.06.02.20120469; this version posted June 5, 2020. The copyright holder for this preprint (which was not certified by peer review) is the author/funder, who has granted medRxiv a license to display the preprint in perpetuity.

\title{
Table $S 4$ cont'd
}

\begin{abstract}
It is made available under a CC-BY-NC-ND 4.0 International license.
\end{abstract}

\begin{tabular}{|c|c|c|c|c|c|c|c|}
\hline SPX & 9.35 & 6.12 & -3.23 & -9.37 & 0.00 & 0.00 & -1.00 \\
\hline SLC27A2 & 6.94 & 3.56 & -3.38 & -10.42 & 0.00 & 0.00 & -1.00 \\
\hline RORB & 8.92 & 5.52 & -3.40 & -10.54 & 0.00 & 0.00 & -1.00 \\
\hline SLC27A2 & 7.34 & 3.56 & -3.78 & -13.75 & 0.00 & 0.00 & -1.00 \\
\hline
\end{tabular}




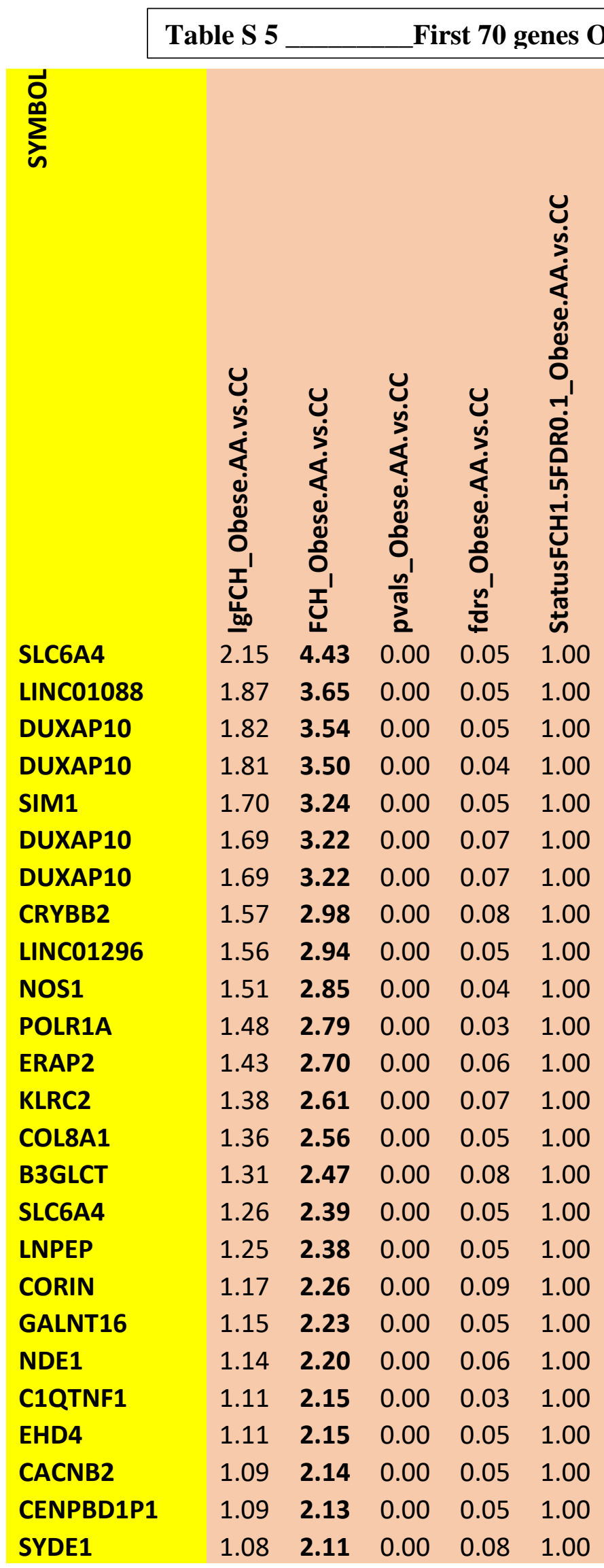




\begin{tabular}{|c|c|c|c|c|c|}
\hline \multicolumn{2}{|l|}{ Table S 5 co } & \multirow[b]{2}{*}{2.10} & \multirow[b]{2}{*}{0.00} & \multirow[b]{2}{*}{0.08} & \multirow[b]{2}{*}{1.00} \\
\hline CCL8 & 1.07 & & & & \\
\hline ETV6 & 1.07 & 2.09 & 0.00 & 0.04 & 1.00 \\
\hline OASL & 1.04 & 2.05 & 0.00 & 0.07 & 1.00 \\
\hline C8orf34-AS1 & 1.01 & 2.02 & 0.00 & 0.08 & 1.00 \\
\hline CSF1 & 1.00 & 2.00 & 0.00 & 0.06 & 1.00 \\
\hline EHD4 & 0.98 & 1.98 & 0.00 & 0.08 & 1.00 \\
\hline CACNB2 & 0.97 & 1.96 & 0.00 & 0.04 & 1.00 \\
\hline PTGER3 & 0.95 & 1.94 & 0.00 & 0.10 & 1.00 \\
\hline TCEA3 & 0.96 & 1.94 & 0.00 & 0.08 & 1.00 \\
\hline LINC00632 & 0.94 & 1.92 & 0.00 & 0.05 & 1.00 \\
\hline PYHIN1 & 0.94 & 1.92 & 0.00 & 0.05 & 1.00 \\
\hline HSPB6 & 0.94 & 1.92 & 0.00 & 0.06 & 1.00 \\
\hline C1QTNF2 & 0.93 & 1.91 & 0.00 & 0.09 & 1.00 \\
\hline FZD8 & 0.93 & 1.90 & 0.00 & 0.08 & 1.00 \\
\hline C10orf54 & 0.93 & 1.90 & 0.00 & 0.03 & 1.00 \\
\hline KIF6 & 0.92 & 1.89 & 0.00 & 0.03 & 1.00 \\
\hline NMNAT2 & 0.89 & 1.85 & 0.00 & 0.06 & 1.00 \\
\hline VSTM2L & 0.88 & 1.85 & 0.00 & 0.03 & 1.00 \\
\hline GOLM1 & 0.89 & 1.85 & 0.00 & 0.03 & 1.00 \\
\hline MAP9 & 0.88 & 1.85 & 0.00 & 0.05 & 1.00 \\
\hline HSDL2 & 0.88 & 1.84 & 0.00 & 0.07 & 1.00 \\
\hline TCEANC2 & 0.88 & 1.84 & 0.00 & 0.04 & 1.00 \\
\hline MGST1 & 0.88 & 1.84 & 0.00 & 0.10 & 1.00 \\
\hline GARNL3 & 0.88 & 1.84 & 0.00 & 0.07 & 1.00 \\
\hline LOC101927648 & 0.86 & 1.82 & 0.00 & 0.06 & 1.00 \\
\hline ZNF555 & 0.87 & 1.82 & 0.00 & 0.08 & 1.00 \\
\hline LTBP2 & 0.86 & 1.82 & 0.00 & 0.06 & 1.00 \\
\hline PAPPA & 0.86 & 1.81 & 0.00 & 0.08 & 1.00 \\
\hline ACVRL1 & 0.85 & 1.81 & 0.00 & 0.05 & 1.00 \\
\hline USP42 & 0.86 & 1.81 & 0.00 & 0.10 & 1.00 \\
\hline CFP & 0.86 & 1.81 & 0.00 & 0.08 & 1.00 \\
\hline ZNF683 & 0.86 & 1.81 & 0.00 & 0.08 & 1.00 \\
\hline RPP25 & 0.85 & 1.80 & 0.00 & 0.05 & 1.00 \\
\hline KCNJ12 & 0.83 & 1.78 & 0.00 & 0.08 & 1.00 \\
\hline MMAB & 0.83 & 1.77 & 0.00 & 0.03 & 1.00 \\
\hline CYTH4 & 0.82 & 1.77 & 0.00 & 0.07 & 1.00 \\
\hline RDH16 & 0.82 & 1.77 & 0.00 & 0.07 & 1.00 \\
\hline ATP6V0E2 & 0.82 & 1.77 & 0.00 & 0.09 & 1.00 \\
\hline$H \times 2$ & 0.81 & 1.76 & 0.00 & 0.05 & 1.00 \\
\hline
\end{tabular}




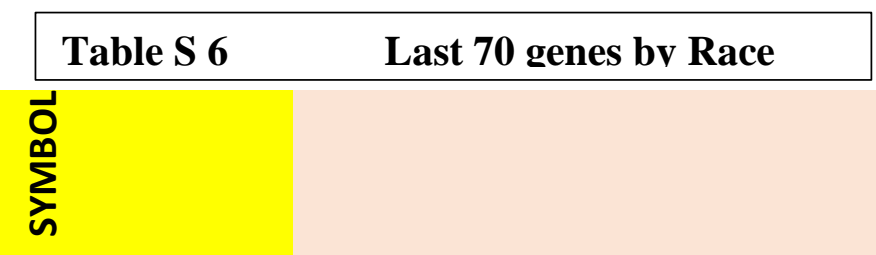

$\begin{array}{llllll}\text { PTGR2 } & -1.27 & \mathbf{- 2 . 4 1} & 0.00 & 0.10 & -1.00 \\ \text { DNAJB14 } & -1.28 & \mathbf{- 2 . 4 2} & 0.00 & 0.08 & -1.00 \\ \text { SLC1A6 } & -1.29 & \mathbf{- 2 . 4 4} & 0.00 & 0.05 & -1.00 \\ \text { ZCCHC11 } & -1.28 & \mathbf{- 2 . 4 4} & 0.00 & 0.05 & -1.00 \\ \text { SRSF1 } & -1.29 & \mathbf{- 2 . 4 5} & 0.00 & 0.04 & -1.00 \\ \text { OGT } & -1.31 & \mathbf{- 2 . 4 7} & 0.00 & 0.07 & -1.00 \\ \text { C50rf24 } & -1.31 & \mathbf{- 2 . 4 9} & 0.00 & 0.07 & -1.00 \\ \text { MLLT10 } & -1.31 & \mathbf{- 2 . 4 9} & 0.00 & 0.07 & -1.00 \\ \text { LOC101927391 } & -1.31 & \mathbf{- 2 . 4 9} & 0.00 & 0.08 & -1.00 \\ \text { RPRD1A } & -1.32 & \mathbf{- 2 . 5 0} & 0.00 & 0.07 & -1.00 \\ \text { MBNL1 } & -1.33 & \mathbf{- 2 . 5 1} & 0.00 & 0.07 & -1.00 \\ \text { RASSF5 } & -1.34 & \mathbf{- 2 . 5 3} & 0.00 & 0.10 & -1.00 \\ \text { THUMPD3- } & & & & & \\ \text { AS1 } & 1.34 & \mathbf{- 2 . 5 3} & 0.00 & 0.06 & -1.00 \\ \text { BLOC1S5 } & -1.34 & \mathbf{- 2 . 5 4} & 0.00 & 0.09 & -1.00 \\ \text { WDR72 } & -1.35 & \mathbf{- 2 . 5 4} & 0.00 & 0.04 & -1.00 \\ \text { SGPP1 } & -1.36 & \mathbf{- 2 . 5 7} & 0.00 & 0.07 & -1.00 \\ \text { THUMPD3- } & & & & & \\ \text { AS1 } & -1.37 & \mathbf{- 2 . 5 9} & 0.00 & 0.05 & -1.00 \\ \text { B3GNT2 } & -1.39 & \mathbf{- 2 . 6 3} & 0.00 & 0.09 & -1.00 \\ \text { DENR } & -1.40 & \mathbf{- 2 . 6 3} & 0.00 & 0.05 & -1.00 \\ \text { FRG1JP } & -1.41 & \mathbf{- 2 . 6 5} & 0.00 & 0.05 & -1.00 \\ \text { LOC284578 } & -1.42 & \mathbf{- 2 . 6 7} & 0.00 & 0.06 & -1.00 \\ \text { GATM } & -1.42 & \mathbf{- 2 . 6 8} & 0.00 & 0.09 & -1.00 \\ \text { TSC22D1 } & -1.43 & \mathbf{- 2 . 7 0} & 0.00 & 0.06 & -1.00\end{array}$




\begin{tabular}{|c|c|c|c|c|c|c|}
\hline LOC283788 & -1.44 & -2.72 & 0.00 & 0.07 & -1.00 & Table S 6 cont'd \\
\hline MFSD8 & -1.45 & -2.73 & 0.00 & 0.06 & -1.00 & \\
\hline NUP50 & -1.45 & -2.74 & 0.00 & 0.04 & -1.00 & \\
\hline TMED2 & -1.46 & -2.75 & 0.00 & 0.10 & -1.00 & \\
\hline INO80D & -1.46 & -2.75 & 0.00 & 0.06 & -1.00 & \\
\hline PPP4R4 & -1.46 & -2.76 & 0.00 & 0.07 & -1.00 & \\
\hline AP4E1 & -1.47 & -2.77 & 0.00 & 0.08 & -1.00 & \\
\hline RRN3P1 & -1.47 & -2.78 & 0.00 & 0.03 & -1.00 & \\
\hline LYZ & -1.49 & -2.81 & 0.00 & 0.10 & -1.00 & \\
\hline CRYBB2P1 & -1.53 & -2.89 & 0.00 & 0.09 & -1.00 & \\
\hline ANLN & -1.54 & -2.91 & 0.00 & 0.05 & -1.00 & \\
\hline FCGR3B & -1.54 & -2.92 & 0.00 & 0.03 & -1.00 & \\
\hline CCNG2 & -1.57 & -2.97 & 0.00 & 0.09 & -1.00 & \\
\hline RSRP1 & -1.57 & -2.97 & 0.00 & 0.06 & -1.00 & \\
\hline CEACAM5 & -1.58 & -2.99 & 0.00 & 0.09 & -1.00 & \\
\hline SMARCA2 & -1.61 & -3.04 & 0.00 & 0.09 & -1.00 & \\
\hline RICTOR & -1.61 & -3.05 & 0.00 & 0.08 & -1.00 & \\
\hline YWHAZ & -1.63 & -3.09 & 0.00 & 0.07 & -1.00 & \\
\hline UBE2Z & -1.64 & -3.12 & 0.00 & 0.05 & -1.00 & \\
\hline SULT1E1 & -1.66 & -3.15 & 0.00 & 0.05 & -1.00 & \\
\hline PRPF39 & -1.66 & -3.16 & 0.00 & 0.05 & -1.00 & \\
\hline TMED2 & -1.69 & -3.23 & 0.00 & 0.07 & -1.00 & \\
\hline SULT1E1 & -1.72 & -3.30 & 0.00 & 0.03 & -1.00 & \\
\hline NFIA & -1.79 & -3.46 & 0.00 & 0.08 & -1.00 & \\
\hline SOX9 & -1.96 & -3.89 & 0.00 & 0.10 & -1.00 & \\
\hline CFTR & -1.99 & -3.98 & 0.00 & 0.03 & -1.00 & \\
\hline UBA6 & -2.06 & -4.16 & 0.00 & 0.07 & -1.00 & \\
\hline GABRP & -2.07 & -4.19 & 0.00 & 0.03 & -1.00 & \\
\hline FMO2 & -2.13 & -4.37 & 0.00 & 0.07 & -1.00 & \\
\hline CDH11 & -2.32 & -4.98 & 0.00 & 0.05 & -1.00 & \\
\hline SCGB2A2 & -2.60 & -6.04 & 0.00 & 0.10 & -1.00 & \\
\hline
\end{tabular}




\section{Supplementary Figure S1:}
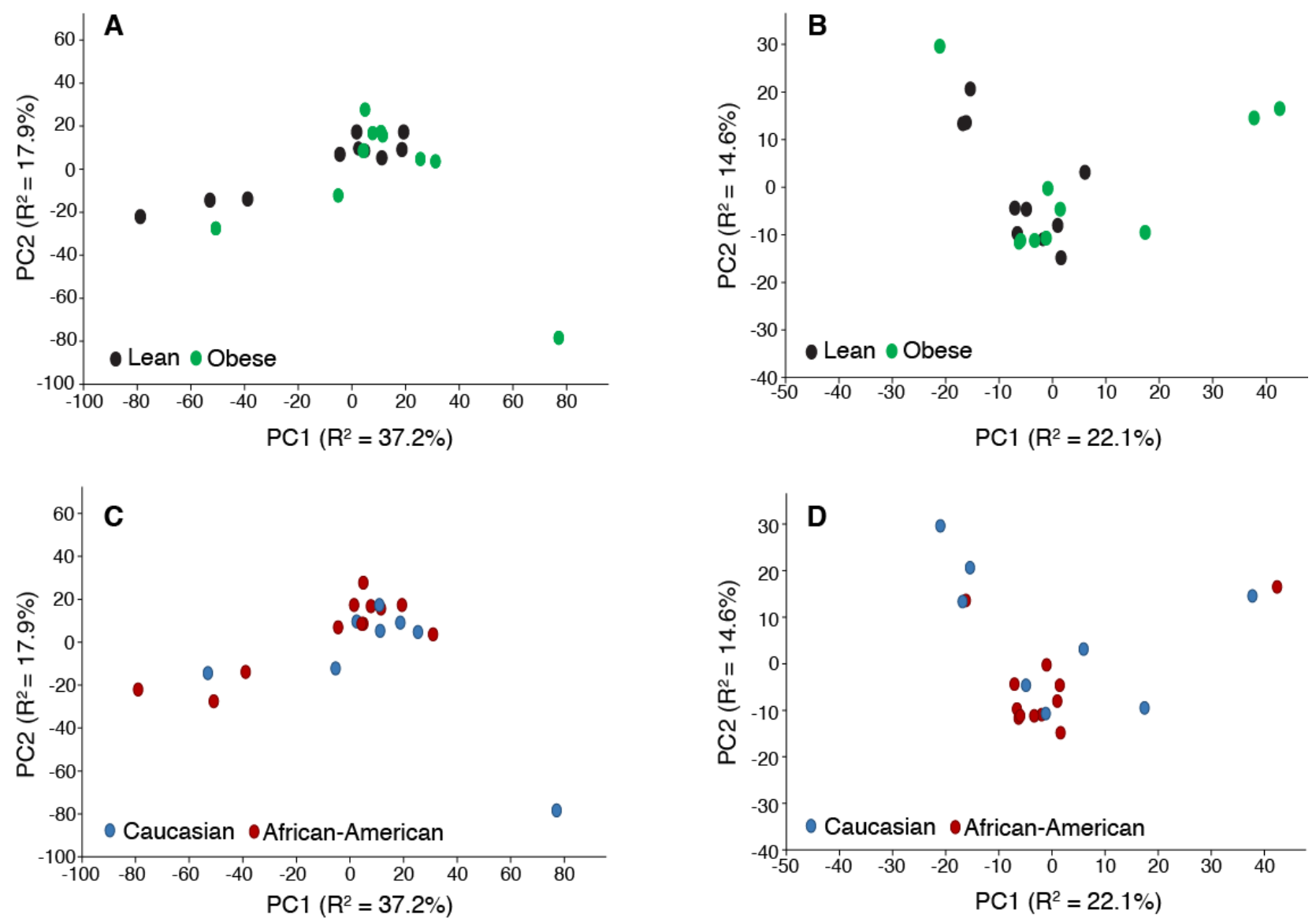

PCA models comparing the metabolic content of swab samples collected from obese and nonobese (A, positive ionization mode; B, negative ionization mode), and Caucasian and African American individuals ( $\mathrm{C}$, positive ionization mode; $\mathrm{D}$, negative ionization mode). Metabolic profiles were measured by UPLC-MS. 